\title{
Adsorption Behavior of Crystal Violet and Congo Red Dyes on Heat-Treated Brazilian Palygorskite: Kinetic, Isothermal and Thermodynamic Studies
}

\author{
Vanderlane Cavalcanti Silva 1D, Maria Eduarda Barbosa Araújo ${ }^{1}$, Alisson Mendes Rodrigues 2,*(D), \\ Maria do Bom Conselho Vitorino ${ }^{1}$, Juliana Melo Cartaxo ${ }^{2}$, Romualdo Rodrigues Menezes ${ }^{2}$ (D) \\ and Gelmires Araújo Neves ${ }^{2}$ (D) \\ 1 Graduate Program in Materials Science and Engineering (PPG-CEMat), Federal University of Campina \\ Grande, Av. Aprígio Veloso-882, Bodocongó, Campina Grande 58429-900, PB, Brazil; \\ vanderlanecavalcanti@outlook.com (V.C.S.); mariaeduardaba@hotmail.com (M.E.B.A.); \\ adrsames@gmail.com (M.d.B.C.V.) \\ 2 Laboratory of Materials Technology (LTM), Department of Materials Engineering, Federal University of \\ Campina Grande, Av. Aprígio Veloso-882, Bodocongó, Campina Grande 58429-900, PB, Brazil; \\ julianamelo25@gmail.com (J.M.C.); romualdo.menezes@ufcg.edu.br (R.R.M.); \\ gelmires.neves@ufcg.edu.br (G.A.N.) \\ * Correspondence: alisson.mendes@professor.ufcg.edu.br
}

\section{check for} updates

Citation: Silva, V.C.; Araújo, M.E.B.; Rodrigues, A.M.; Vitorino, M.d.B.C.; Cartaxo, J.M.; Menezes, R.R.; Neves, G.A. Adsorption Behavior of Crystal Violet and Congo Red Dyes on Heat-Treated Brazilian Palygorskite: Kinetic, Isothermal and Thermodynamic Studies. Materials 2021, 14, 5688. https://doi.org/ $10.3390 /$ ma14195688

Academic Editor: Dimitrios Papoulis

Received: 29 July 2021

Accepted: 23 August 2021

Published: 30 September 2021

Publisher's Note: MDPI stays neutral with regard to jurisdictional claims in published maps and institutional affiliations.

Copyright: (c) 2021 by the authors. Licensee MDPI, Basel, Switzerland. This article is an open access article distributed under the terms and conditions of the Creative Commons Attribution (CC BY) license (https:// creativecommons.org/licenses/by/ $4.0 /)$.

\begin{abstract}
The effect of heat treatment on the adsorptive capacity of a Brazilian palygorskite to remove the dyes crystal violet (CV) and congo red (CR) was investigated. The natural palygorskite was calcined at different temperatures $\left(300,500\right.$ and $\left.700{ }^{\circ} \mathrm{C}\right)$ for $4 \mathrm{~h}$. Changes in the palygorskite structure were evaluated using X-ray diffraction, X-ray fluorescence, thermogravimetric and differential thermal analysis, $\mathrm{N}_{2}$ adsorption/desorption and Fourier transform infrared spectroscopy. The adsorption efficiency of $\mathrm{CV}$ and $\mathrm{CR}$ was investigated through the effect of initial concentration, contact time, temperature, $\mathrm{pH}$ and dosage of adsorbent. The calcination increased the adsorption capacity of palygorskite, and the greatest adsorption capacity of $\mathrm{CV}$ and $\mathrm{CR}$ dyes occurred in the sample calcined at $700{ }^{\circ} \mathrm{C}$ (Pal-700T). The natural and calcined samples at 300 and $500{ }^{\circ} \mathrm{C}$ followed the Freundlich isothermal model, while the Pal-700T followed the Langmuir isothermal model. Adsorption kinetics results were well described by the Elovich model. Pal-700T showed better adsorption performance at basic $\mathrm{pH}$, with removal greater than $98 \%$, for both dyes. Pal-700T proved to be a great candidate for removing cationic and anionic dyes present in water.
\end{abstract}

Keywords: palygorskite; adsorption; crystal violet; congo red; water treatment

\section{Introduction}

Water pollution due to the effluents discharged daily by various industries, such as textiles, pharmaceuticals, paper, plastics and cosmetics, is considered one of the biggest environmental problems in the world [1,2]. Effluents derived from these industries are often rich in dyes $[3,4]$. Dye pollution is a threat to human health and aquatic ecosystems since most of them are highly toxic, mutagenic, allergenic and carcinogenic, and can quickly accumulate in living cells, harming an entire food chain [5-7].

Crystal violet $(\mathrm{CV})$ is a triphenylmethane cationic dye commonly used in the textile, paper and medical industries [8,9]. CV is considered a biohazardous substance due to its highly genotoxic, toxic, mutagenic and carcinogenic nature [10-12]. In addition, CV has a very intense color, and its presence in the aquatic environment, even at low concentrations (for example, $1 \mathrm{mg} / \mathrm{L}$ ), increases water turbidity, making photosynthesis by aquatic plants impossible [12]. Human exposure to CV can cause eye irritation, increased heart rate, permanent blindness, respiratory disease, kidney failure, chemical cystitis and cancer [13-17]. 
Congo red (CR) is a diazo anionic dye used primarily in the textile and paper industries $[18,19]$. The effluent contaminated with CR reduces the oxygen levels in the water, suffocating the aquatic flora and fauna [20]. CR is considered the most harmful and used dye in the world; its degradation can generate amine, benzidine and other potentially carcinogenic species [21-23]. In humans, CR can cause general weakness, gastrointestinal irritation, anorexia, mutation, lung and bladder cancers [24-28]. CV and CR dyes have a complex structure, are highly stable to light and heat and are difficult to degrade biologically $[29,30]$. Therefore, the separation of CV and CR dyes from the water has become a great challenge, which has motivated the search for efficient techniques to solve or minimize the environmental pollution caused [29,31-33].

Numerous techniques have been developed to remove dyes from wastewater, such as coagulation/flocculation [34], ion exchange [35], membrane filtration [36], oxidation [37], electrochemical degradation [38] and adsorption [39]. Among these, adsorption is one of the most attractive techniques due to its versatility, simplicity, ecologically correct and high efficiency [2,40-43]. Some adsorbent materials can have a high cost, such as activated carbon $[44,45]$. This motivated the search for alternative adsorbents with high efficiency and economically viable, such as zeolites [46], clays [47] and biomass [48].

Clays are often used as adsorbents for economic feasibility and environmental importance due to their low cost, abundance, immediate availability, non-toxicity and high adsorptive properties [49-51]. Due to its fibrous structure and high surface area, the palygorskite clay has gained considerable prominence as an adsorbent to remove various types of pollutants [44,45,52-56].

Several physical and chemical modifications are used in palygorskite to improve its adsorption properties, mainly acid activation $[44,45,50]$ and surface modification [57-59]. However, few studies have addressed how heat treatment can influence palygorskite structure and adsorption properties [60-62]. Furthermore, little has been explored about how heat treatment can affect the structure of palygorskite found in Brazil. Thus, this work aimed to analyze the effect of heat treatment on Brazilian palygorskite's structure and evaluate its potential in treating contaminated water with crystal violet and congo red dyes.

\section{Materials and Methods}

\subsection{Raw Materials}

Palygorskite clay was supplied by União Brasileira de Mineração S.A. (UBM, Soledade, $\mathrm{PB}$, Brazil) with a particle size of $0.074 \mathrm{~mm}$. The crystal violet (CV) and Congo red (CR) dyes were purchased from Synth (Diadema, SP, Brazil) and Dinâmica Química (Indaiatuba, SP, Brazil), respectively. Hydrochloric acid and ammonium hydroxide were purchased from VETEC (Duque de Caxias, RJ, Brazil).

\subsection{Heat Treatment}

The heat treatment protocol involved three steps: (i) the samples were heated $\left(5{ }^{\circ} \mathrm{C} / \mathrm{min}\right)$ from room temperature to the heat treatment temperatures $(300,500$ and $700{ }^{\circ} \mathrm{C}$ ), (ii) 4-h isothermal treatment was carried out and (iii) the oven was turned off and then cooled to room temperature. The heat treatment was carried out in a muffle furnace (mod. 3000, EDG, São Carlos, SP, Brazil). The samples treated at $300{ }^{\circ} \mathrm{C}, 500{ }^{\circ} \mathrm{C}$ and $700{ }^{\circ} \mathrm{C}$ were named Pal-300T, Pal-500T and Pal-700T, respectively. The sample without heat treatment was called Pal.

\subsection{Characterizations}

X-ray diffraction (XRD-6000, Shimadzu, Kyoto, Japan) was performed using $\mathrm{CuK} \alpha$ $(\lambda=1.54 \AA)$, operated at $40 \mathrm{kV}$ and $30 \mathrm{~mA}$, in $2 \theta$ angular range of $5-50^{\circ}$ and $0.02^{\circ}$ of step size $[63,64]$. Chemical analysis was determined using X-ray fluorescence spectrometry (EDX-720, Shimadzu, Kyoto, Japan). Infrared spectra with Fourier transform (FTIR) were recorded in the spectral range from $4000 \mathrm{~cm}^{-1}$ to $400 \mathrm{~cm}^{-1}$, with 32 scans and $4 \mathrm{~cm}^{-1}$ 
resolutions, using KBr pellets (Vertex-70, Bruker, Billerica, MA, USA). Thermogravimetric (TGA) and differential thermal analysis (DTA) were performed under air atmosphere, with a heating rate of $10{ }^{\circ} \mathrm{C} / \mathrm{min}$ (DTG-60H, Shimadzu, Kyoto, Japan). The average pore diameter and surface area were determined by nitrogen adsorption measurements at $77 \mathrm{~K}$ using an Auto-sorb iQ Station 1 analyzer (Anton Paar, Graz, Austria). The BrunnerEmmett-Teller (BET) method $[65,66]$ was used to calculate the surface area. All nitrogen sorption data were analyzed using the Quantachrome ${ }^{\circledR}$ ASiQwin ${ }^{\mathrm{TM}}$ software (Anton Paar, Graz, Austria).

\subsection{Batch Adsorption Experiments}

The effects of contact time, initial dye concentration, $\mathrm{pH}$, amount of adsorbent and temperature were studied in the adsorption of CV and CR dyes. During the experiment, one parameter was varied while the other parameters remained constant. The adsorption experiments were carried out in vials containing $20 \mathrm{~mL}$ of dye solutions. The adsorbentsolution systems were stirred $(150 \mathrm{rpm})$ at $25{ }^{\circ} \mathrm{C}$ for up to $360 \mathrm{~min}$. The parameters of the contact time, initial dye concentration, $\mathrm{pH}$, dosage of adsorbent and temperature were analyzed in the range of $15-360 \mathrm{~min}, 2.5-200 \mathrm{mg} / \mathrm{L}, 3-11,10-40 \mathrm{mg}$ e $25-55{ }^{\circ} \mathrm{C}$, respectively. After the adsorption process, the samples were centrifuged at $3600 \mathrm{rpm}$ for $5 \mathrm{~min}$. The concentrations of both dyes left in the solutions were determined from the measured absorbance values in the supernatant at $582.5 \mathrm{~nm}$ and $501 \mathrm{~nm}$ for $\lambda_{\max }$ of CV and CR, respectively. These experiments were performed in a UV spectrophotometer (UV1800, Shimadzu). The equilibrium adsorbed amount ( $\left.\mathrm{q}_{\mathrm{e}}\right)$ of $\mathrm{CV}$ and CR and the removal percentage of both dyes (\%R) were estimated using Equations (1) and (2):

$$
\begin{gathered}
\mathrm{q}_{\mathrm{e}}=\left[\left(\mathrm{C}_{\mathrm{o}}-\mathrm{C}_{\mathrm{e}}\right) \mathrm{V}\right] / \mathrm{m}, \\
\% \mathrm{R}=\left[\left(\mathrm{C}_{\mathrm{o}}-\mathrm{C}_{\mathrm{e}}\right) / \mathrm{C}_{\mathrm{o}}\right] \times 100,
\end{gathered}
$$

where $\mathrm{q}_{\mathrm{e}}(\mathrm{mg} / \mathrm{g})$ is the adsorption capacity, $\mathrm{C}_{\mathrm{o}}(\mathrm{mg} / \mathrm{L})$ and $\mathrm{C}_{\mathrm{e}}(\mathrm{mg} / \mathrm{L})$ are the initial and equilibrium concentrations, respectively. $\mathrm{V}(\mathrm{L})$ is the volume of the solution and $\mathrm{m}(\mathrm{g})$ the mass of the palygorskite samples.

Ethanol was used as a desorption medium to remove dye particles adsorbed on the samples. Adsorbents loaded with CV and CR were desorbed using $60 \mathrm{~mL}$ of ethanol and stirred at $150 \mathrm{rpm}$ for $1 \mathrm{~h}$. Then, the adsorbents were filtered, washed with distilled water, dried, and used again for the subsequent adsorption-desorption cycles.

\section{Results and Discussion}

\subsection{Characterization of Natural and Heat-Treated Palygorskite}

The X-ray diffraction patterns of natural and heat-treated palygorskite samples $\left(300,500\right.$ and $\left.700{ }^{\circ} \mathrm{C}\right)$ are shown in Figure 1. As expected, the natural sample showed reflections of palygorskite (ICCD 21-0958), quartz (ICCD 46-1045) and dolomite (ICCD 36-0426) $[45,67,68]$. According to the heat treatment applied, different changes in the crystal structure were observed. For example, there was only a slight decrease in the characteristic reflections of palygorskite for the samples treated at $300{ }^{\circ} \mathrm{C}$. Such behavior happened because there is a loss of zeolitic water at this temperature and a partial loss of coordinated water [69-71]. It is still possible to observe peaks characteristic of palygorskite in the Pal-500T sample; however, these reflections disappeared after heat-treatment at $700{ }^{\circ} \mathrm{C}$ (Pal-700T). The loss of crystal identity in the Pal-700T sample occurs due to the total loss of coordinated water and irreversible dehydroxylation $[61,72,73]$. The characteristic reflections of quartz were unchanged, even after treatment at $700{ }^{\circ} \mathrm{C}$ for $4 \mathrm{~h}[61,74]$. Calcite $\left(\mathrm{CaCO}_{3}, \mathrm{ICDD} 89-1305\right)$ was identified in the Pal-700T sample. The occurrence of calcite is related to the first stage of dolomite decomposition, which involves the nucleation and growth of $\mathrm{CaCO}_{3}$ particles [61,75-77]. 


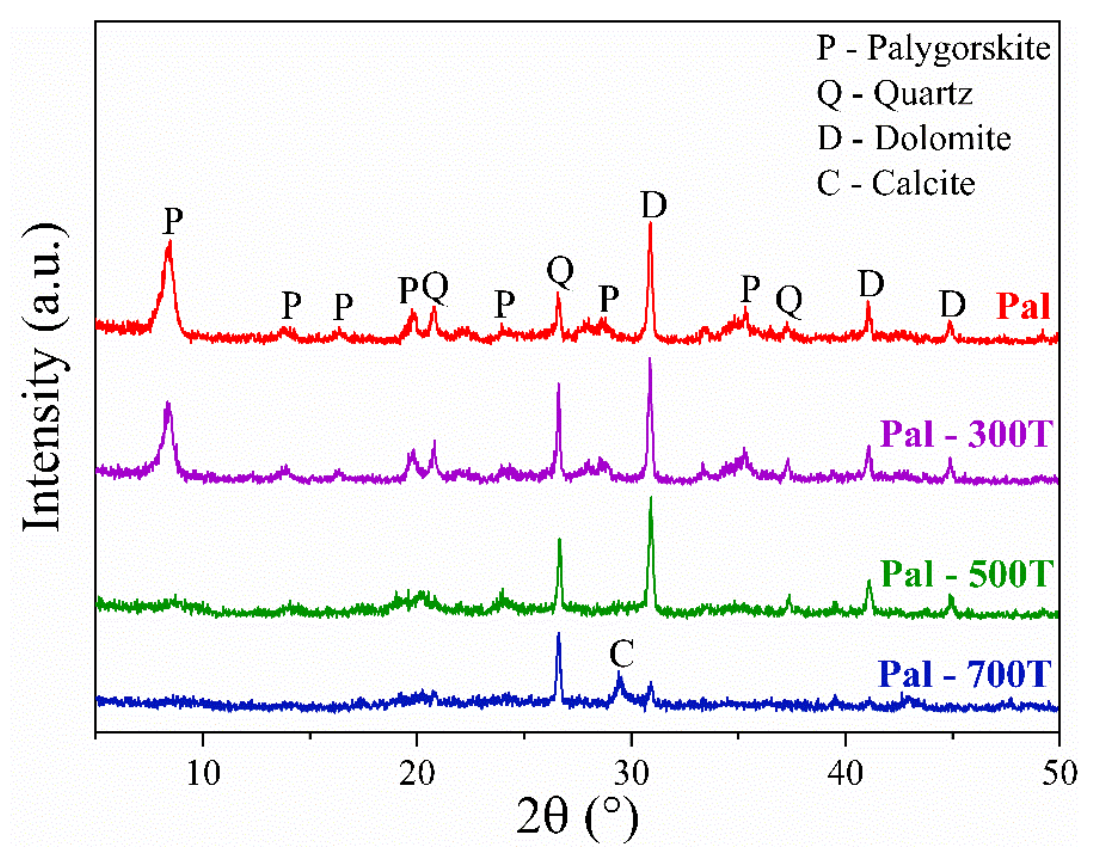

Figure 1. Palygorskite XRD patterns before and after heat treatment at different temperatures.

The chemical compositions of the natural and heat-treated samples are listed in Table 1. It was observed that the Pal sample is mainly composed of $\mathrm{SiO}_{2}, \mathrm{MgO}$ and $\mathrm{Al}_{2} \mathrm{O}_{3}$, which confirms the presence of the clay mineral palygorskite since this is a hydrated silicate of magnesium and aluminum [78]. The heat-treated samples maintained their $\mathrm{SiO}_{2}$ and $\mathrm{Al}_{2} \mathrm{O}_{3}$ contents with increasing temperatures. At $700{ }^{\circ} \mathrm{C}$, together with the appearance of calcite particles, as shown in the $\mathrm{XRD}$, there is the nucleation and growth of $\mathrm{MgO}$ particles and $\mathrm{CO}_{2}$ release, according to the equation: $\mathrm{CaMg}\left(\mathrm{CO}_{3}\right)_{2} \leftrightarrows \mathrm{CaCO}_{3}+\mathrm{MgO}+\mathrm{CO}_{2}$ [75]. Such behavior explains the increase in $\mathrm{MgO}$ content in the Pal-700T sample. It was also observed that the other oxides varied for each calcination temperature. These results were associated with progressive loss of zeolitic water molecules and condensation of $(-\mathrm{OH})$ groups in the clay crystal structure due to calcination [72].

Table 1. Chemical composition (wt \%) of natural and heat-treated palygorskite samples $(300,500$ and $700{ }^{\circ} \mathrm{C}$ ). The margin of error was $3 \%$.

\begin{tabular}{ccccc}
\hline Sample & Pal & Pal-300T & Pal-500T & Pal-700T \\
\hline Oxides (\%) & & 51.80 & 52.72 & 52.02 \\
$\mathrm{SiO}_{2}$ & 52.78 & 14.54 & 14.43 & 15.27 \\
$\mathrm{MgO}^{\mathrm{Al}_{2} \mathrm{O}_{3}}$ & 13.91 & 12.70 & 12.89 & 12.92 \\
$\mathrm{CaO}^{\mathrm{Fe}} \mathrm{O}_{3}$ & 13.48 & 12.77 & 12.11 & 12.09 \\
$\mathrm{~K}_{2} \mathrm{O}$ & 11.92 & 5.56 & 5.33 & 5.25 \\
Other Oxides & 5.29 & 0.93 & 0.94 & 0.96 \\
\hline
\end{tabular}

The thermogravimetric (TGA), derivative thermogravimetric (DTGA) and differential thermal (DTA) curves of the natural and heat-treated palygorskite are shown in Figure 2. Four mass loss events can be identified on Pal's TGA-DTGA curves. The first event occurred at $23-125{ }^{\circ} \mathrm{C}$ with a mass loss of $6.54 \%$ and is related to the evaporation of water physically adsorbed on the surface of the palygorskite [79]. The second event $\left(125-230{ }^{\circ} \mathrm{C}\right.$ ) presented a mass loss of $2.46 \%$ and is related to the loss of zeolitic water molecules located in the palygorskite channels [72]. The third event observed between 230-530 ${ }^{\circ} \mathrm{C}$ was attributed to coordinated water loss and condensation of silanol and aluminol groups $[54,80]$, which resulted in a mass loss of $5.26 \%$. The last event occurred at 
530-720 ${ }^{\circ} \mathrm{C}$ and showed a mass loss of $11.74 \%$ was caused by dolomite decomposition [81]. These four endothermic events resulted in a total mass loss of $26 \%$. The DTA curve confirmed these events with endothermic peaks in the same temperature range as the mass losses in the TGA-DTGA curves. The peaks were attributed to: (i) evaporation of physically adsorbed water molecules [82], (ii) release of zeolitic water molecules [73], (iii) coordinated water removal, as well as the condensation of surface groups [83] and (iv) dolomite decomposition [84].
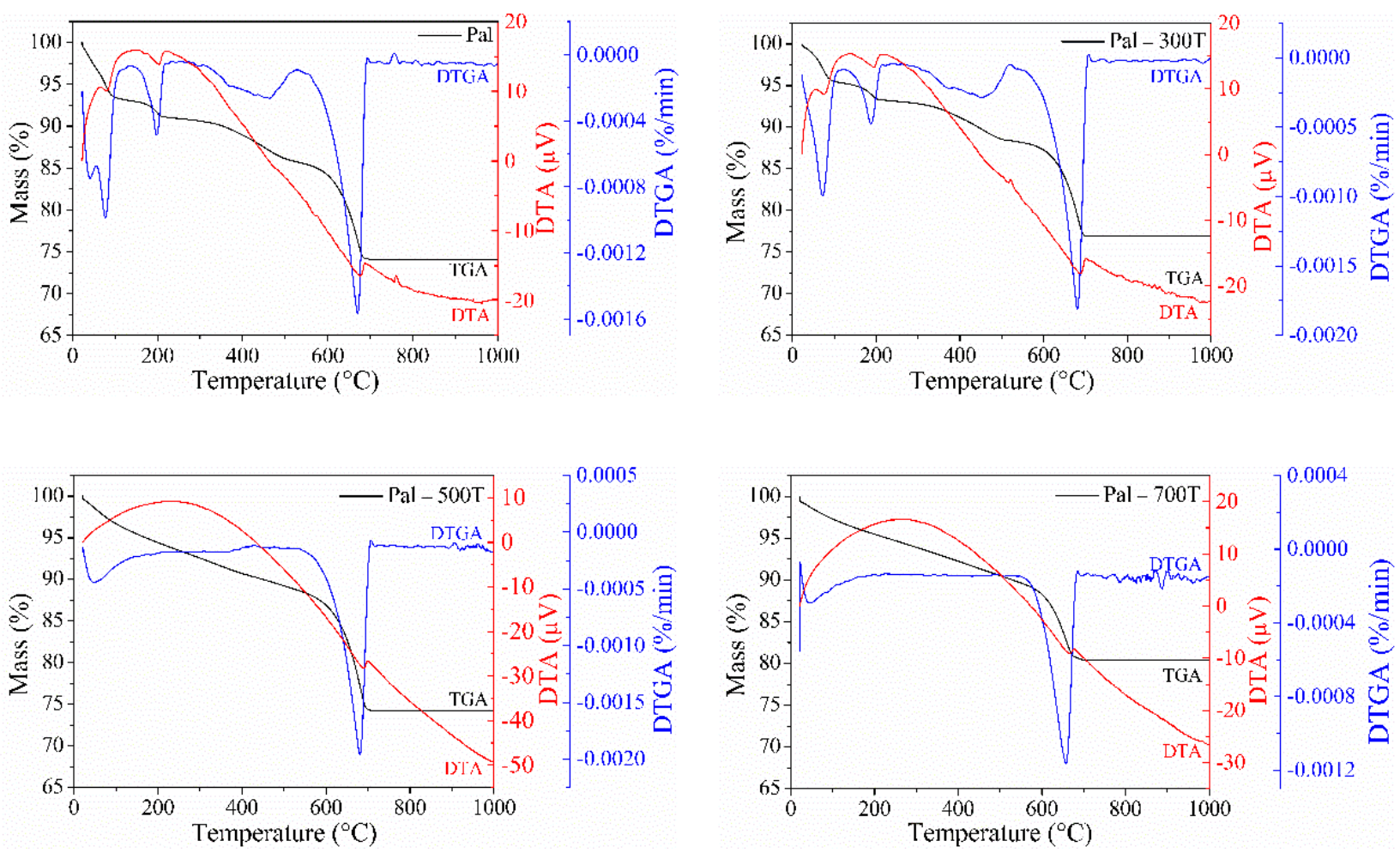

Figure 2. TGA-DTGA-DTA curves of palygorskite clay before and after heat treatment, obtained at a heating rate of $10{ }^{\circ} \mathrm{C} / \mathrm{min}$ and under an air atmosphere.

The Pal-300T sample showed mass losses and peaks (endothermic) similar to those observed in the raw palygorskite. However, it obtained a smaller mass loss in the second event $(2.15 \%)$, while the Pal sample achieved a loss of $2.46 \%$. This decrease in mass loss occurred due to the partial removal of zeolitic water during heat treatment [85]. In the Pal-500T and Pal-700T samples, there is less mass loss and the absence of peaks related to the removal of zeolitic and coordinated waters; this is a consequence of the elimination of these waters during calcination since the activation temperature was higher than the temperature of elimination of zeolitic and coordinated waters.

The specific surface area $\left(\mathrm{S}_{\mathrm{BET}}\right)$ and average pore diameter $\left(\mathrm{D}_{\mathrm{p}}\right)$ of the raw and heattreated palygorskite samples are listed in Table 2. After heat treatment, the $\mathrm{S}_{\mathrm{BET}}$ values decreased as the calcination temperature increased. Such behavior can be explained by the deformation of the palygorskite structure during dehydration and irreversible dehydroxylation, which causes pore blockage $[60,61,75,86]$. The $D_{p}$ values increased as the calcination temperature increased, probably due to the formation of new and larger pores during calcination [60]. 
Table 2. Specific surface area $\left(\mathrm{S}_{\mathrm{BET}}\right)$ and average pore diameter $\left(\mathrm{D}_{\mathrm{p}}\right)$ of palygorskite before and after heat treatment.

\begin{tabular}{ccc}
\hline Sample & Specific Surface Area $\left(\mathbf{m}^{2} / \mathbf{g}\right)$ & Average Pore Diameter $(\mathbf{n m})$ \\
\hline Pal & 80.4 & 14.3 \\
Pal-300T & 79.8 & 14.4 \\
Pal-500T & 67.6 & 16.6 \\
Pal-700T & 63.2 & 18.1 \\
\hline
\end{tabular}

\subsection{Adsorption Experiments}

\subsubsection{Effect of Initial Concentration and Adsorption Isotherms}

The effect of the initial concentration of crystal violet $\left(\mathrm{C}_{\mathrm{o}}^{\mathrm{CV}}\right)$ and congo red $\left(\mathrm{C}_{\mathrm{o}}^{\mathrm{CR}}\right)$ dyes on the adsorption capacity $\left(\mathrm{q}_{\mathrm{e}}\right)$ of palygorskite before and after heat treatment is shown in Figure 3a,b. Different concentrations of CV and CR (2.5 to $200 \mathrm{mg} / \mathrm{L})$ were tested under the following experimental conditions: contact time of $360 \mathrm{~min}, \mathrm{pH} \mathrm{7,20} \mathrm{mg}$ of adsorbent at $25^{\circ} \mathrm{C}$. It is evident that the adsorption capacity of the samples increased significantly with increasing $C_{o}^{C V}$ and $C_{o}^{C R}$. This is because the increase in $C_{o}^{C V}$ and $C_{o}^{C R}$ contributed to increasing the driving force at the solid-liquid interface that overcomes the mass transfer resistance, leading to increased adsorption capacity $[87,88]$. The maximum CV adsorption capacity (Figure $3 a)$ followed the order: Pal-700T $(186.5 \mathrm{mg} / \mathrm{g}$ ) $>$ Pal-500T $(80.1 \mathrm{mg} / \mathrm{g})>$ Pal-300T $(78.6 \mathrm{mg} / \mathrm{g})>\mathrm{Pal}(57.5 \mathrm{mg} / \mathrm{g})$. Comparing with the Pal sample, the adsorbed amount increased by 300\%, 39\% and 37\% to Pal-700T, Pal-500T and Pal-300T, respectively. The maximum CR adsorption capacity (Figure $3 \mathrm{~b}$ ) followed the order: Pal-700T $(144.7 \mathrm{mg} / \mathrm{g})>$ Pal-500T $(59.8 \mathrm{mg} / \mathrm{g})>$ Pal-300T $(41.1 \mathrm{mg} / \mathrm{g})>$ Pal $(30.6 \mathrm{mg} / \mathrm{g})$. Comparing the heat-treated samples with Pal, the adsorbed amount increased by $373 \%, 95.3 \%$ and $34.2 \%$ to Pal-700T, Pal-500T and Pal-300T, respectively. These results show that the adsorption performance of Pal for both dyes was amplified after heat treatment.
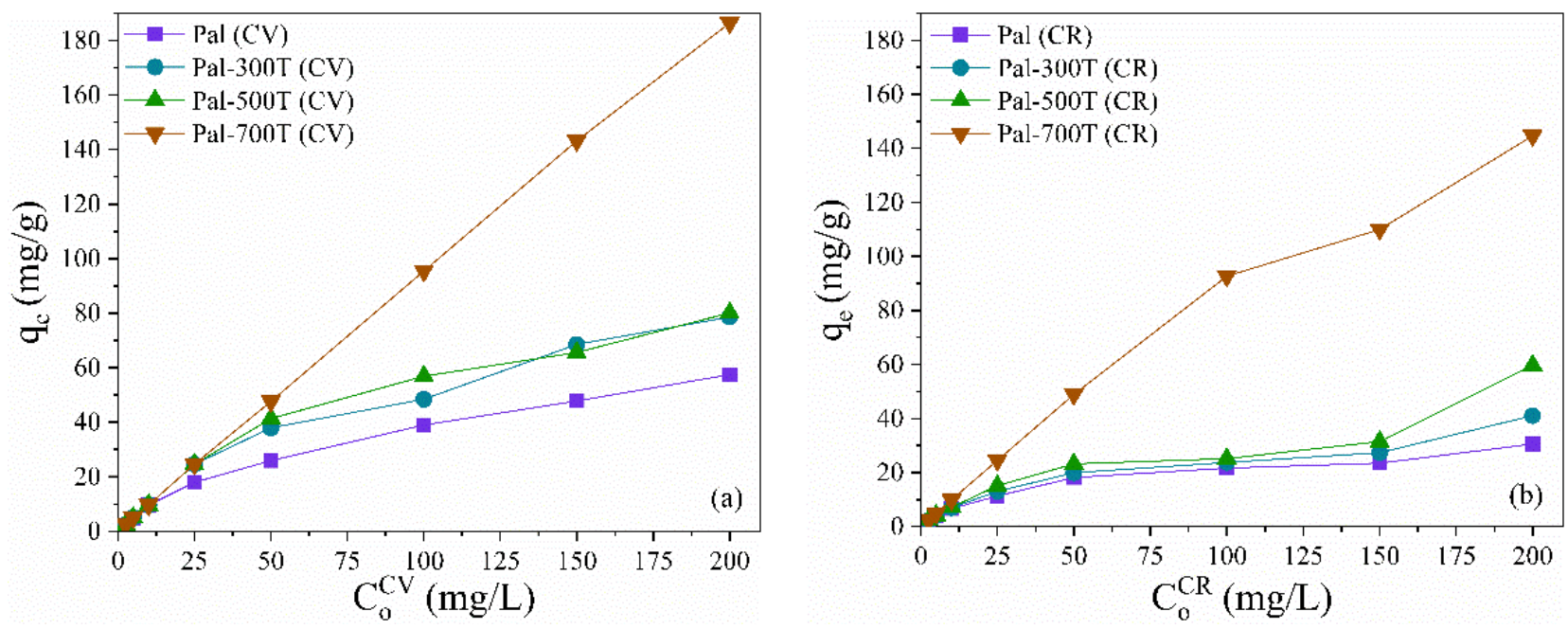

Figure 3. Effect of initial concentration on the adsorption capacity of natural and heat-treated palygorskite to remove (a) CV and (b) CR.

To better understand the type of interaction that occurs between the adsorbate and the adsorbent, the experimental data of $\mathrm{CV}$ and $\mathrm{CR}$ adsorption were fitted to the nonlinear isothermal models of Langmuir, Freundlich, DR and Temkin, corresponding to Equations (3)-(6) respectively [89-91]:

$$
\begin{gathered}
\mathrm{q}_{\mathrm{e}}=\left(\mathrm{q}_{\max } \mathrm{K}_{\mathrm{L}} \mathrm{C}_{\mathrm{e}}\right) /\left(1+\mathrm{K}_{\mathrm{L}} \mathrm{C}_{\mathrm{e}}\right), \\
\mathrm{q}_{\mathrm{e}}=\mathrm{K}_{\mathrm{F}} \mathrm{C}_{\mathrm{e}}^{1 / \mathrm{n}},
\end{gathered}
$$




$$
\begin{gathered}
\mathrm{q}_{\mathrm{e}}=\mathrm{q}_{\mathrm{D}} \exp \left(-\mathrm{K}_{\mathrm{DR}} \varepsilon^{2}\right), \varepsilon=\mathrm{R} \mathrm{T} \ln \left(1+1 / \mathrm{C}_{\mathrm{e}}\right), \\
\mathrm{q}_{\mathrm{e}}=\left(\mathrm{RT} / \mathrm{b}_{\mathrm{T}}\right) \ln \mathrm{A}_{\mathrm{T}}+\left(\mathrm{RT} / \mathrm{b}_{\mathrm{T}}\right) \ln \mathrm{C}_{\mathrm{e}},
\end{gathered}
$$

where $C_{e}(\mathrm{mg} / \mathrm{L})$ is the equilibrium dye concentration and $\mathrm{q}_{\mathrm{e}}(\mathrm{mg} / \mathrm{g})$ is the equilibrium dye adsorbed amount. $\mathrm{K}_{\mathrm{L}}(\mathrm{L} / \mathrm{mg})$ is the Langmuir constant representing the activation energy in adsorption and $\mathrm{q}_{\max }(\mathrm{mg} / \mathrm{g})$, which refers to the maximum adsorption capacity. $\mathrm{K}_{\mathrm{F}}$ $\left((\mathrm{mg} / \mathrm{g})(\mathrm{L} / \mathrm{mg})^{1 / \mathrm{n}}\right)$ and $\mathrm{n}$ are the Freundlich constants, where $\mathrm{K}_{\mathrm{F}}$ indicates the adsorption capacity and $\mathrm{n}$ corresponds to the adsorption intensity. $\mathrm{K}_{\mathrm{DR}}\left(\mathrm{mol}^{2} / \mathrm{J}^{2}\right)$ and $\varepsilon$ are the DubininRadushkevich constants, while $\mathrm{q}_{\mathrm{D}}(\mathrm{mg} / \mathrm{g})$ is the theoretical isothermal saturation capacity. $\mathrm{R}(8314 \mathrm{~J} / \mathrm{mol} \mathrm{K})$ is the universal gas constant and $\mathrm{T}(\mathrm{K})$ is the absolute temperature. $\mathrm{A}_{\mathrm{T}}$ $(\mathrm{L} / \mathrm{mg})$ is the Temkin constant referring to the maximum binding energy and $\mathrm{b}_{\mathrm{T}}(\mathrm{J} / \mathrm{mol})$ is the heat of adsorption. All values were calculated from the fit of the mathematical models to the experimental data (Figure $4 \mathrm{a}-\mathrm{d}$ ). The results of the mathematical adjustments are shown in Table 3.
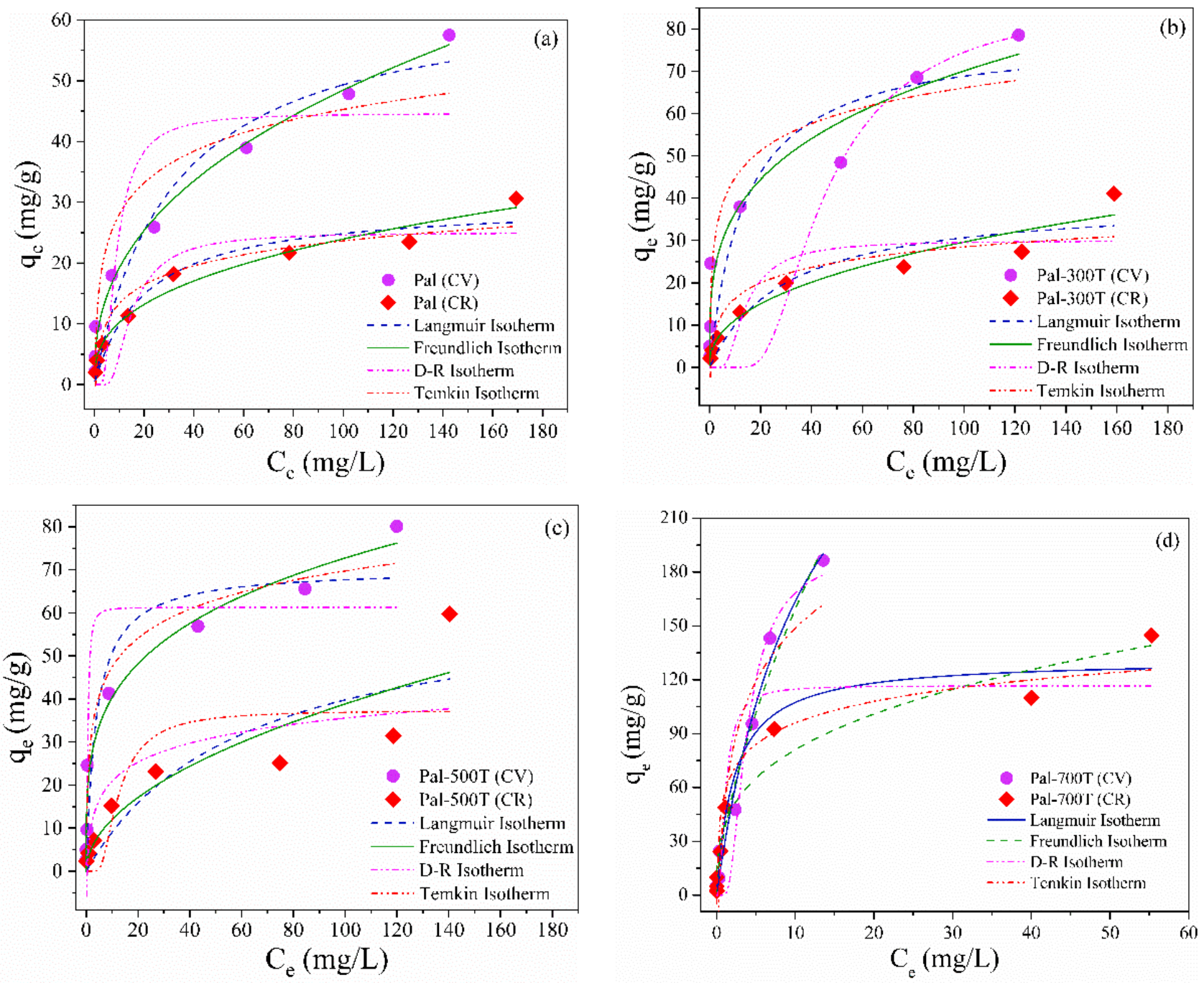

Figure 4. Nonlinear adsorption isotherms (Langmuir, Freundlich, D-R and Temkin) of CV and CR for (a) Pal, (b) Pal-300T, (c) Pal-500T and (d) Pal-700T. 
Table 3. Langmuir, Freundlich, D-R and Temkin isothermal parameters for CV and CR adsorption.

\begin{tabular}{|c|c|c|c|c|}
\hline Sample & Dye & & Model & \\
\hline \multirow{4}{*}{ Pal } & & \multicolumn{3}{|c|}{ Langmuir Isotherm } \\
\hline & & $\mathrm{q}_{\max }(\mathrm{mg} / \mathrm{g})$ & $\mathrm{K}_{\mathrm{L}}(\mathrm{L} / \mathrm{mg})$ & $\mathrm{R}^{2}$ \\
\hline & $\mathrm{CV}$ & 64.7 & 0.03 & 0.93 \\
\hline & CR & 29.9 & 0.05 & 0.94 \\
\hline \multirow{2}{*}{ Pal-300T } & $\mathrm{CV}$ & 78.7 & 0.07 & 0.83 \\
\hline & CR & 39.7 & 0.03 & 0.88 \\
\hline \multirow{2}{*}{ Pal-500T } & $\mathrm{CV}$ & 70.3 & 0.26 & 0.88 \\
\hline & CR & 63.9 & 0.02 & 0.75 \\
\hline \multirow{2}{*}{ Pal-700T } & $\mathrm{CV}$ & 189.3 & 0.87 & 0.98 \\
\hline & CR & 136.1 & 0.46 & 0.96 \\
\hline \multicolumn{5}{|c|}{ Freundlich Isotherm } \\
\hline \multirow{3}{*}{ Pal } & & $1 / n$ & $\mathrm{~K}_{\mathrm{F}}(\mathrm{mg} / \mathrm{g})(\mathrm{L} / \mathrm{mg})^{1 / \mathrm{n}}$ & $\mathrm{R}^{2}$ \\
\hline & $\mathrm{CV}$ & 0.26 & 11.0 & 0.99 \\
\hline & $\mathrm{CR}$ & 0.42 & 4.1 & 0.97 \\
\hline \multirow{2}{*}{ Pal-300T } & $\mathrm{CV}$ & 0.26 & 19.1 & 0.95 \\
\hline & $\mathrm{CR}$ & 0.43 & 4.2 & 0.94 \\
\hline \multirow{2}{*}{ Pal-500T } & $\mathrm{CV}$ & 0.28 & 22.4 & 0.97 \\
\hline & CR & 0.51 & 4.9 & 0.81 \\
\hline \multirow{2}{*}{ Pal-700T } & $\mathrm{CV}$ & 0.65 & 35.5 & 0.97 \\
\hline & CR & 0.71 & 39.1 & 0.94 \\
\hline \multirow{4}{*}{ Pal } & & & D-R Isotherm & \\
\hline & & $\mathrm{q}_{\mathrm{D}}(\mathrm{mg} / \mathrm{g})$ & $\mathrm{K}_{\mathrm{DR}}\left(\mathrm{mol}^{2} / \mathrm{J}^{2}\right)$ & $\mathrm{R}^{2}$ \\
\hline & $\mathrm{CV}$ & 44.6 & $1.1 \times 10^{-5}$ & 0.79 \\
\hline & $\mathrm{CR}$ & 25.1 & $2.9 \times 10^{-5}$ & 0.82 \\
\hline \multirow{2}{*}{ Pal-300T } & $\mathrm{CV}$ & 61.3 & $2.6 \times 10^{-4}$ & 0.57 \\
\hline & CR & 29.9 & $2.6 \times 10^{-5}$ & 0.75 \\
\hline \multirow{2}{*}{ Pal-500T } & $\mathrm{CV}$ & 87.3 & $1.2 \times 10^{-7}$ & 0.84 \\
\hline & CR & 37.4 & $2.1 \times 10^{-5}$ & 0.61 \\
\hline \multirow{4}{*}{ Pal-700T } & $\mathrm{CV}$ & 191.5 & $2.3 \times 10^{-6}$ & 0.96 \\
\hline & $\mathrm{CR}$ & 116.7 & $2.9 \times 10^{-7}$ & 0.91 \\
\hline & & & Temkin Isotherm & \\
\hline & & $\mathrm{b}_{\mathrm{T}}(\mathrm{J} / \mathrm{mol})$ & $\mathrm{A}_{\mathrm{T}}(\mathrm{L} / \mathrm{mg})$ & $\mathrm{R}^{2}$ \\
\hline \multirow{2}{*}{ Pal } & $\mathrm{CV}$ & 329.6 & 4.2 & 0.89 \\
\hline & CR & 551.3 & 1.9 & 0.93 \\
\hline \multirow{2}{*}{ Pal-300T } & $\mathrm{CV}$ & 267.9 & 12.8 & 0.91 \\
\hline & CR & 468.2 & 2.2 & 0.84 \\
\hline \multirow{2}{*}{ Pal-500T } & $\mathrm{CV}$ & 255.2 & 13.2 & 0.95 \\
\hline & $\mathrm{CR}$ & 389.2 & 2.7 & 0.66 \\
\hline \multirow{2}{*}{ Pal-700T } & $\mathrm{CV}$ & 57.6 & 25.5 & 0.90 \\
\hline & $\mathrm{CR}$ & 143.1 & 3.2 & 0.94 \\
\hline
\end{tabular}

Based on the correlation coefficient values $\left(\mathrm{R}^{2}\right)$, the Langmuir model was the one that best described the CV and CR adsorption process in the Pal-700T sample, as it exhibited $R^{2}$ values closer to the unity. The best mathematical adjusts to the Langmuir model suggest that the adsorption of CV on Pal-700T occurs mainly via the chemisorption process, in which a monolayer of the adsorbate is deposited on the surface of the palygorskite $[54,92,93]$. The higher value of $\mathrm{K}_{\mathrm{L}}$ means greater interaction between the adsorbent and adsorbate [94,95]; thus, Pal-700T has a greater interaction with CV molecules, while Pal has a lower interaction, which is consistent with the results obtained experimentally. 
On the other hand, the result of the mathematical adjustments performed for the samples Pal, Pal-300T and Pal-500T showed that the Freundlich model was the one that best fit the experimental data of adsorption of $C V$ and $C R$, as it presents $R^{2}$ values closest to 1 . Values of $1 / \mathrm{n}$ indicated that adsorption was favorable for all samples [94]. The Freundlich model is the best isothermal model implies that, based on its assumption, the adsorption of both dyes on Pal, Pal-300T and Pal-500T occurs on a heterogeneous surface with the formation of multiple layers $[96,97]$.

\subsubsection{Effect of Contact Time and Kinetic Study}

$\mathrm{CV}$ and $\mathrm{CR}$ solutions with initial concentrations of $50 \mathrm{mg} / \mathrm{L}$ for an adsorbent amount of $20 \mathrm{mg}$ at $25^{\circ} \mathrm{C}$ and $\mathrm{pH} 7$ were used to study the adsorption kinetics. Figure 5 a shows the amount of CV adsorbed on Pal, Pal-300T, Pal-500T and Pal-700T as a function of contact time. Initially, adsorption was fast for all samples as about $40 \%$ of $\mathrm{CV}$ adsorption occurred within the first $30 \mathrm{~min}$. Such a result is due to the active sites available on the surface of the adsorbent in the early stages [86] and the strong electrostatic interaction between the negatively charged palygorskite surface and the CV that has cationic character [98]. Over time, adsorption gradually slowed down until equilibrium was reached within $240 \mathrm{~min}$. When equilibrium was reached, the adsorption capacity and CV removal value in Pal were $26.02 \mathrm{mg} / \mathrm{g}$ and 52\%, respectively. While the Pal-300T, Pal-500T and Pal-700T samples removed about $78 \%(38.92 \mathrm{mg} / \mathrm{g}), 82 \%(41.38 \mathrm{mg} / \mathrm{g})$ and $95 \%(47.3 \mathrm{mg} / \mathrm{g})$, respectively.
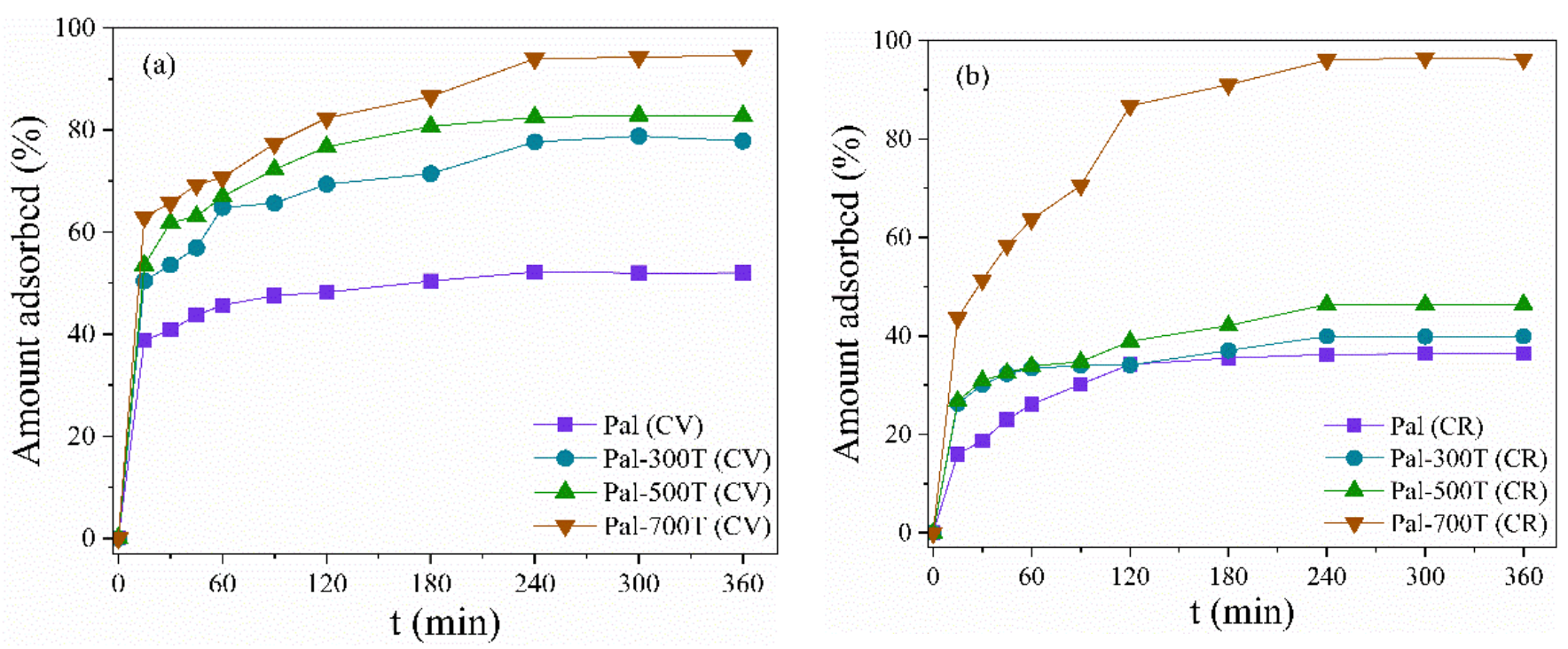

Figure 5. Effect of contact time on the adsorption of (a) CV and (b) CR in palygorskite before and after heat treatment.

Figure $5 b$ illustrates the effect of contact time of $C R$ adsorbed on samples before and after heat treatment. For $\mathrm{CR}$, the adsorption kinetics was relatively slow, except for Pal-700T. Equilibrium was reached within $240 \mathrm{~min}$ with removal of $36 \%(18.17 \mathrm{mg} / \mathrm{g}), 40 \%$ $(20 \mathrm{mg} / \mathrm{g})$ and $46 \%(23.21 \mathrm{mg} / \mathrm{g})$ for Pal, Pal-300T and Pal-500T, respectively. The Pal-700T sample showed rapid adsorption of CR, where in the first $30 \mathrm{~min}$, about $51 \%$ of the dye had been removed. When equilibrium was reached within $240 \mathrm{~min}$, the adsorption capacity of Pal-700T was $48.11 \mathrm{mg} / \mathrm{g}$ with $96 \% \mathrm{CR}$ removed. The results revealed that Pal-700T presents excellent efficiency (greater than $90 \%$ ) for removing cationic and anionic dyes. 
The kinetic parameters were evaluated from Pseudo-first order (Equation (7)), Pseudosecond order (Equation (8)) and Elovich (Equation (9)) models [99,100]:

$$
\begin{gathered}
\mathrm{q}_{\mathrm{t}}=\mathrm{q}_{\mathrm{e}}\left[1-\exp \left(-\mathrm{k}_{1} \mathrm{t}\right)\right], \\
\mathrm{q}_{\mathrm{t}}=\left(\mathrm{q}_{\mathrm{e}}{ }^{2} \mathrm{k}_{2} \mathrm{t}\right) /\left(1+\mathrm{k}_{2} \mathrm{qe}_{\mathrm{e}} \mathrm{t}\right), \\
\mathrm{q}_{\mathrm{t}}=\alpha+\beta \ln \mathrm{t},
\end{gathered}
$$

where $\mathrm{q}_{\mathrm{t}}(\mathrm{mg} / \mathrm{g})$ is the amount of dye adsorbed at time $\mathrm{t}(\mathrm{min})$ and $\mathrm{q}_{\mathrm{e}}(\mathrm{mg} / \mathrm{g})$ is the amount of dye adsorbed at equilibrium. $\mathrm{k}_{1}\left(\mathrm{~min}^{-1}\right)$ and $\mathrm{k}_{2}\left(\mathrm{~min}^{-1}\right)$ are the Pseudo-first order and Pseudo-second order constants, respectively. $\alpha\left(\mathrm{mg}^{-1} \mathrm{~g}^{-1} / \mathrm{min}\right)$ and $\beta(\mathrm{g} / \mathrm{mg})$ are the Elovich constants. Kinetic parameters were calculated from the non-linear curve fit (Figure 6a-d) and are shown in Table 4.
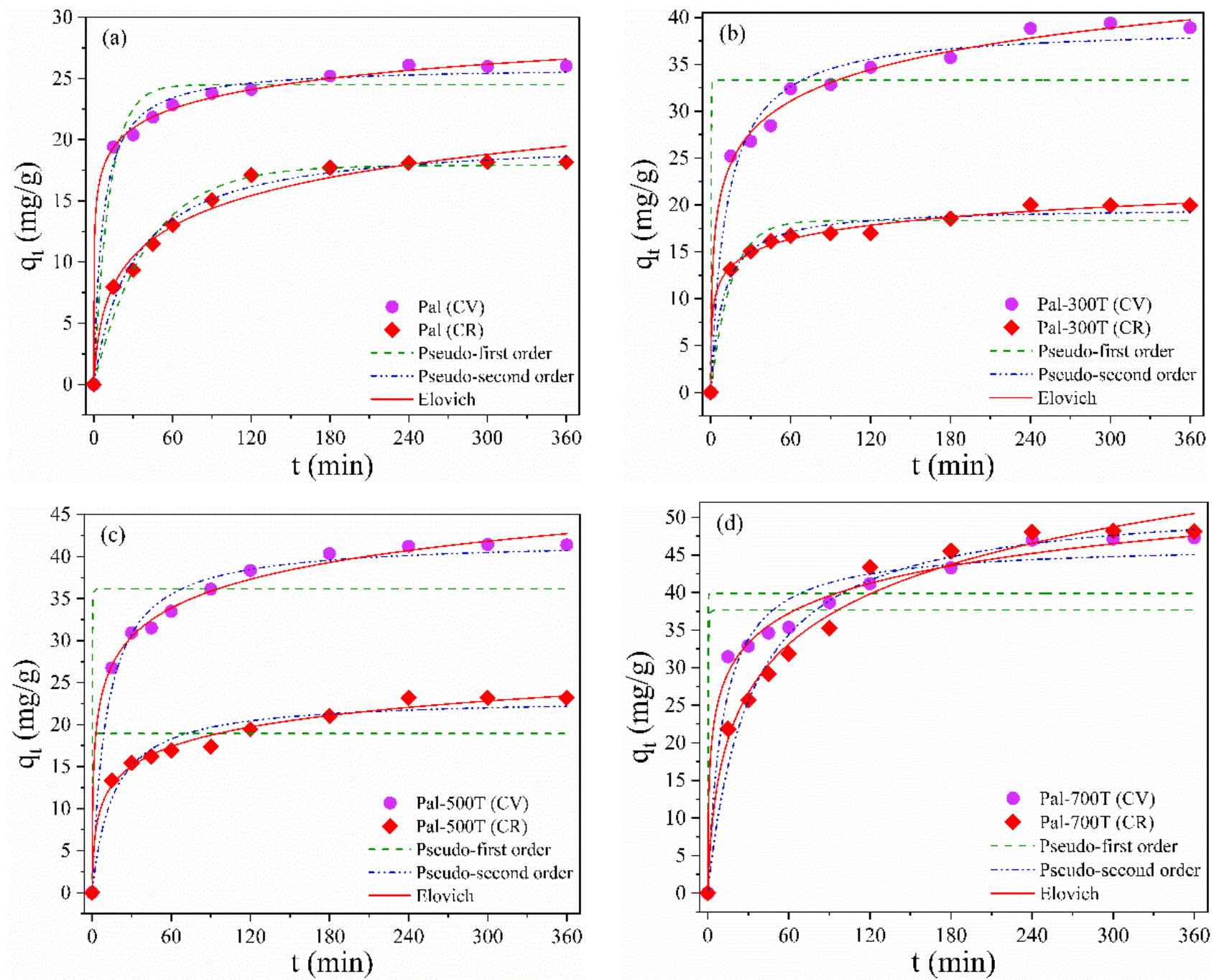

Figure 6. Nonlinear adsorption kinetic models (Pseudo-first order, Pseudo-second order and Elovich) of CV and CR for (a) Pal, (b) Pal-300T, (c) Pal-500T and (d) Pal-700T. 
Table 4. Pseudo-first order, Pseudo-second order and Elovich kinetic parameters for CV and CR adsorption.

\begin{tabular}{|c|c|c|c|c|c|}
\hline Sample & Dye & \multicolumn{4}{|c|}{ Model } \\
\hline \multirow{4}{*}{ Pal } & & \multicolumn{4}{|c|}{ Pseudo-first order } \\
\hline & & $\mathrm{q}_{\exp }(\mathrm{mg} / \mathrm{g})$ & $\mathrm{q}_{\mathrm{cal}}(\mathrm{mg} / \mathrm{g})$ & $\mathrm{k}_{1}\left(\min ^{-1}\right)$ & $\mathrm{R}^{2}$ \\
\hline & $\mathrm{CV}$ & 26 & 24.5 & 0.08 & 0.95 \\
\hline & CR & 18.2 & 20.1 & 0.02 & 0.97 \\
\hline \multirow{2}{*}{ Pal-300T } & $\mathrm{CV}$ & 38.9 & 33.3 & 4.23 & 0.79 \\
\hline & $\mathrm{CR}$ & 20 & 18.4 & 0.07 & 0.94 \\
\hline \multirow{2}{*}{ Pal-500T } & $\mathrm{CV}$ & 41.4 & 36.2 & 5.10 & 0.81 \\
\hline & $\mathrm{CR}$ & 23.2 & 18.9 & 2.04 & 0.71 \\
\hline \multirow{4}{*}{ Pal-700T } & $\mathrm{CV}$ & 47.3 & 39.9 & 8.04 & 0.79 \\
\hline & $\mathrm{CR}$ & 48.1 & 37.7 & 2.68 & 0.54 \\
\hline & & \multicolumn{4}{|c|}{ Pseudo-second order } \\
\hline & & $q_{\exp }(\mathrm{mg} / \mathrm{g})$ & $\mathrm{q}_{\mathrm{cal}}(\mathrm{mg} / \mathrm{g})$ & $\begin{array}{c}\mathrm{k}_{2}(\mathrm{~g} /(\mathrm{mg} \\
\min ))\end{array}$ & $\mathrm{R}^{2}$ \\
\hline \multirow{2}{*}{ Pal } & $\mathrm{CV}$ & 26 & 25.9 & 0.001 & 0.98 \\
\hline & $\mathrm{CR}$ & 18.2 & 17.9 & 0.002 & 0.98 \\
\hline \multirow{2}{*}{ Pal-300T } & $\mathrm{CV}$ & 38.9 & 39.0 & 0.002 & 0.97 \\
\hline & $\mathrm{CR}$ & 20 & 19.7 & 0.006 & 0.98 \\
\hline \multirow{2}{*}{ Pal-500T } & $\mathrm{CV}$ & 41.4 & 41.9 & 0.002 & 0.98 \\
\hline & $\mathrm{CR}$ & 23.2 & 23.1 & 0.003 & 0.95 \\
\hline \multirow{4}{*}{ Pal-700T } & $\mathrm{CV}$ & 47.3 & 46.4 & 0.002 & 0.96 \\
\hline & $\mathrm{CR}$ & 48.1 & 52.6 & 0.005 & 0.97 \\
\hline & & \multicolumn{4}{|c|}{ Elovich } \\
\hline & & & $\begin{array}{c}\alpha \\
\left(\mathrm{mg} \cdot \mathrm{g}^{-1} / \mathrm{min}\right)\end{array}$ & $\begin{array}{c}\beta \\
(\mathrm{g} / \mathrm{mg})\end{array}$ & $\mathrm{R}^{2}$ \\
\hline \multirow{2}{*}{ Pal } & $\mathrm{CV}$ & & 7.7 & 0.4 & 0.99 \\
\hline & CR & & 1.9 & 0.3 & 0.99 \\
\hline \multirow{2}{*}{ Pal-300T } & $\mathrm{CV}$ & & 49.3 & 0.2 & 0.99 \\
\hline & $\mathrm{CR}$ & & 5.2 & 0.5 & 0.99 \\
\hline \multirow{2}{*}{ Pal-500T } & $\mathrm{CV}$ & & 61.9 & 0.2 & 0.99 \\
\hline & CR & & 9.6 & 0.3 & 0.99 \\
\hline \multirow{2}{*}{ Pal-700T } & $\mathrm{CV}$ & & 78.1 & 0.2 & 0.99 \\
\hline & $\mathrm{CR}$ & & 4.8 & 0.1 & 0.99 \\
\hline
\end{tabular}

The Elovich model presented the highest $\mathrm{R}^{2}$ values; therefore, it better describes all samples' CV and CR adsorption kinetics. The better data adjustment to the Elovich model suggests that the adsorption of $\mathrm{CV}$ and $\mathrm{CR}$ in the samples occurs by a dominant chemisorption mechanism with the adsorbents having heterogeneous surfaces [101,102].

\subsubsection{Effect of Temperature and Thermodynamics}

The temperature analysis was carried out in the range of $25-55^{\circ} \mathrm{C}$ with initial solutions of $\mathrm{CV}$ and $\mathrm{CR}$ of $50 \mathrm{mg} / \mathrm{L}$, amount of adsorbent $20 \mathrm{mg}$ at $\mathrm{pH} 7$ for $360 \mathrm{~min}$ and the results obtained are shown in Figure $7 \mathrm{a}, \mathrm{b}$. The results showed an increase in adsorbed amounts with increasing temperature, suggesting that the adsorption of $\mathrm{CV}$ and $\mathrm{CR}$ dyes in palygorskite samples is an endothermic process [103]. This increase is a consequence of the increased mobility of CV and CR ions to the surface of the adsorbent $[45,104]$. 

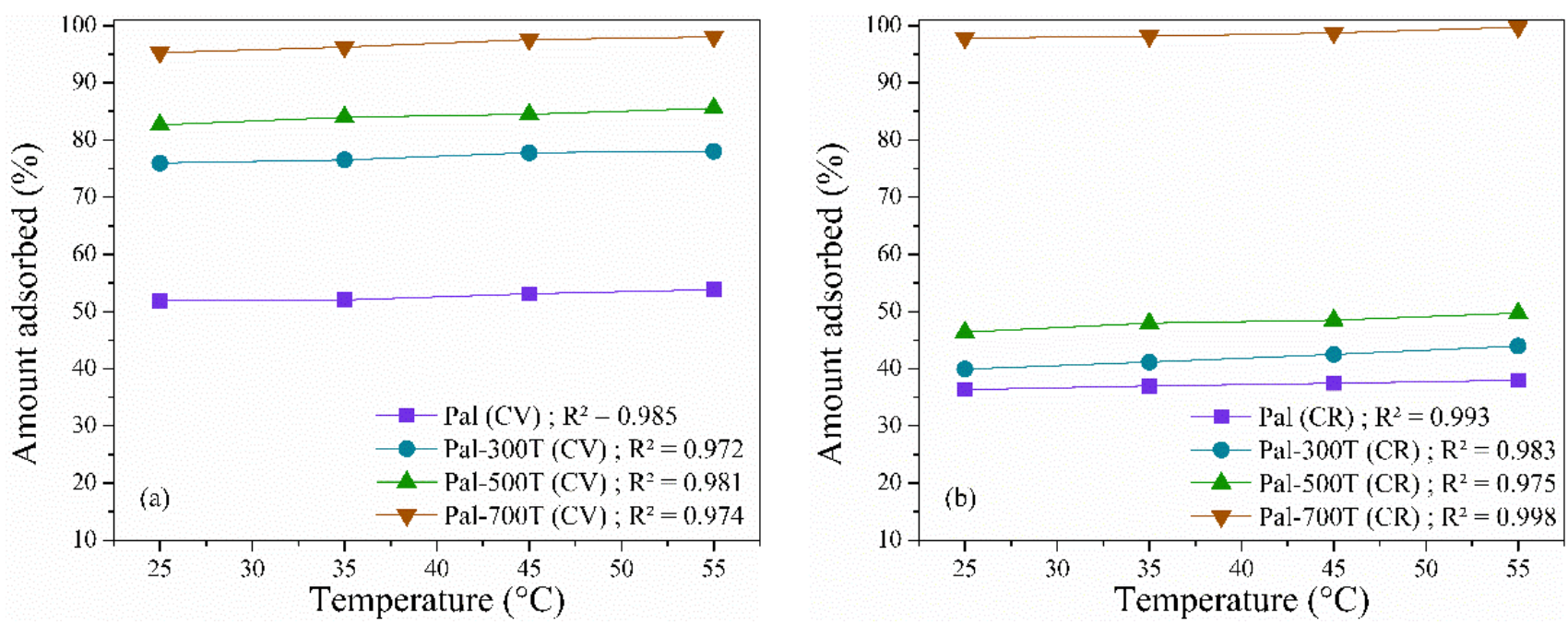

Figure 7. Effect of temperature on (a) CV and (b) CR adsorption on palygorskite before and after heat treatment.

The thermodynamic parameters of the adsorption process on palygorskite adsorbents were determined using the Van't Hoff Equations (Equations (10)-(12)) [105,106]:

$$
\begin{gathered}
\operatorname{Ln} \mathrm{K}_{\mathrm{d}}=(\Delta \mathrm{S} / \mathrm{R})-(\Delta \mathrm{H} / \mathrm{RT}), \\
\Delta \mathrm{G}=-\mathrm{R} \text { T Ln K } \mathrm{d}, \\
\mathrm{K}_{\mathrm{d}}=\mathrm{q}_{\mathrm{e}} / \mathrm{C}_{\mathrm{e}},
\end{gathered}
$$

where $\mathrm{K}_{\mathrm{d}}$ is the distribution coefficient for adsorption and $\Delta \mathrm{H}, \Delta \mathrm{S}$ and $\Delta \mathrm{G}$ are the enthalpy, entropy, and Gibb's energy variations, respectively.

The $\Delta \mathrm{H}$ and $\Delta \mathrm{S}$ values were calculated from the slope and intercept of the Ln Kd versus $1 / \mathrm{T}$ graph (Figure $8 \mathrm{a}, \mathrm{b}$ ). The values of $\Delta \mathrm{H}, \Delta \mathrm{S}$ and $\Delta \mathrm{G}$ are listed in Table 5 . The positive values of $\Delta \mathrm{H}$ confirmed that the adsorption of $\mathrm{CV}$ and $\mathrm{CR}$ in palygorskite samples is an endothermic process [107]. In addition, positive $\Delta S$ values indicated greater randomness at the solid-liquid interface [108] and negative $\Delta G$ values confirmed the spontaneity and viability of adsorption in the entire temperature range studied [31].
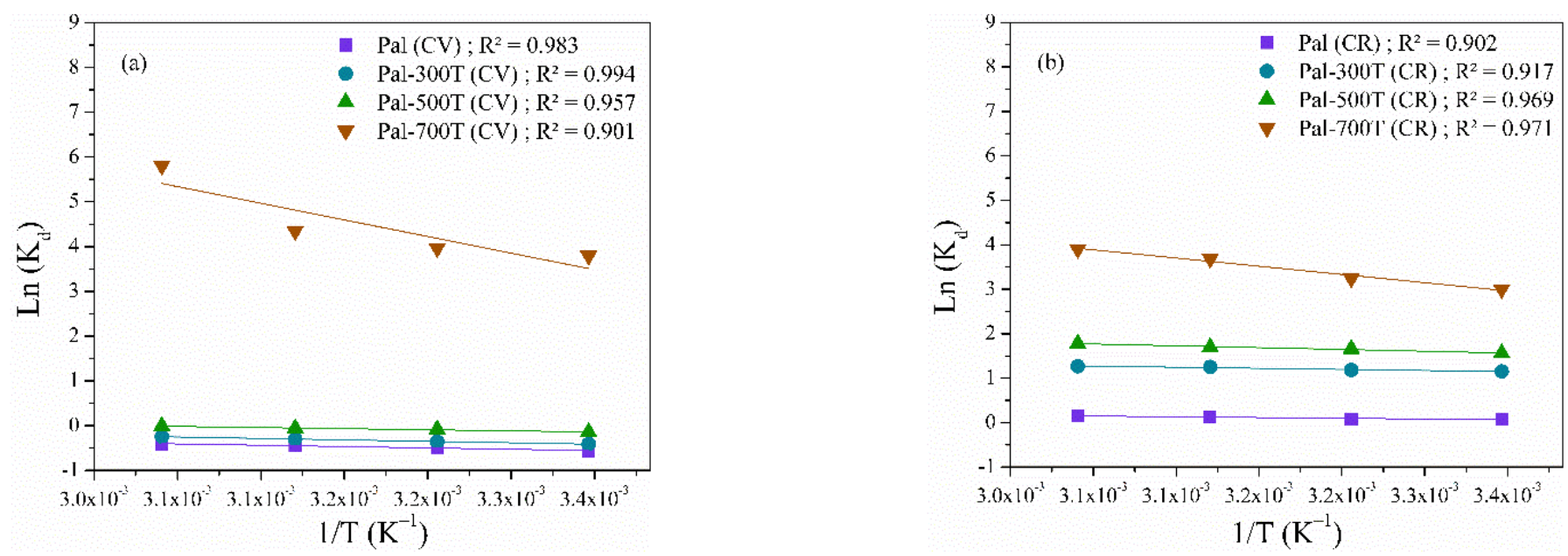

Figure 8. Van't Hoff plots to determine different thermodynamic parameters in dye removal (a) CV and (b) CR. 
Table 5. Thermodynamic parameters for CV and CR adsorption in palygorskite before and after heat treatment at different temperatures.

\begin{tabular}{|c|c|c|c|c|c|c|c|}
\hline \multirow{2}{*}{ Sample } & \multirow{2}{*}{ Dye } & \multicolumn{4}{|c|}{$\Delta \mathrm{G}(\mathrm{kJ} / \mathrm{mol})$} & \multirow{2}{*}{$\begin{array}{c}\Delta \mathrm{H} \\
(\mathrm{kJ} / \mathrm{mol})\end{array}$} & \multirow{2}{*}{$\begin{array}{c}\Delta S(\mathrm{~J} / \mathrm{K} \\
\mathrm{mol})\end{array}$} \\
\hline & & $298 \mathrm{~K}$ & $308 \mathrm{~K}$ & $318 \mathrm{~K}$ & $328 \mathrm{~K}$ & & \\
\hline Pal & $\mathrm{CV}$ & -1.41 & -1.56 & -1.69 & -1.83 & 0.49 & 1.11 \\
\hline Pal-300T & $\mathrm{CV}$ & -0.15 & -0.20 & -0.29 & -0.35 & 0.54 & 1.39 \\
\hline Pal-500T & $\mathrm{CV}$ & -0.66 & -0.79 & -0.90 & -1.01 & 0.41 & 1.24 \\
\hline Pal-700T & $\mathrm{CV}$ & -9.40 & -10.16 & -11.49 & -15.83 & 6.19 & 24.32 \\
\hline Pal & CR & -0.17 & -0.20 & -0.32 & -0.41 & 0.27 & 0.97 \\
\hline Pal-300T & CR & -2.85 & -3.02 & -3.31 & -3.45 & 0.41 & 2.53 \\
\hline Pal-500T & $\mathrm{CR}$ & -3.87 & -4.23 & -4.47 & -4.83 & 0.68 & 3.85 \\
\hline Pal-700T & $\mathrm{CR}$ & -7.43 & -8.29 & -9.76 & -10.64 & 3.08 & 13.31 \\
\hline
\end{tabular}

\subsubsection{Effect of PH Variation}

The $\mathrm{pH}$ is one of the main parameters in the adsorption process, as it influences the surface charge of the adsorbent [3]. The $\mathrm{pH}$ influence on the adsorption capacity of palygorskite samples was analyzed in the $\mathrm{pH}$ range of 3-11 with $20 \mathrm{mg}$ of adsorbent and initial solution of $\mathrm{CV}$ and $\mathrm{CR}$ of $50 \mathrm{mg} / \mathrm{L}$, for $360 \mathrm{~min}$. All experiments were carried out at room temperature $\left(25^{\circ} \mathrm{C}\right)$. The $\mathrm{pH}$ adjustment of the dye solutions was performed using $0.1 \mathrm{M} \mathrm{HCl}$ or $\mathrm{NH}_{4} \mathrm{OH}$. The amount of $\mathrm{CV}$ and $\mathrm{CR}$ adsorbed was strongly dependent on the initial $\mathrm{pH}$ of the solution (Figure $9 \mathrm{a}, \mathrm{b}$ ). The adsorbed amount of CV increased with increasing $\mathrm{pH}$. The adsorbed amount of $\mathrm{CR}$ decreased as the $\mathrm{pH}$ increased (except for Pal-700T). In an acidic medium, $\mathrm{H}^{+}$ions present in the solution protonate the surface of the palygorskite and the functional groups $(-\mathrm{Si}-\mathrm{OH})$ on its surface become-Si-OH ${ }^{2+}[45,53]$. Therefore, the cationic $\mathrm{CV}$ dye adsorption is less efficient, as there is competition between the $\mathrm{H}^{+}$ions and the $\mathrm{CV}$ molecules for the adsorption sites and the repulsive force between the surface of the positively charged adsorbent and the CV molecules decreases the removal efficiency [108]. On the other hand, in an acidic medium, the negatively charged $\mathrm{CR}$ molecules interact electrostatically with the positively charged palygorskite surface, presenting a higher adsorption rate [109].
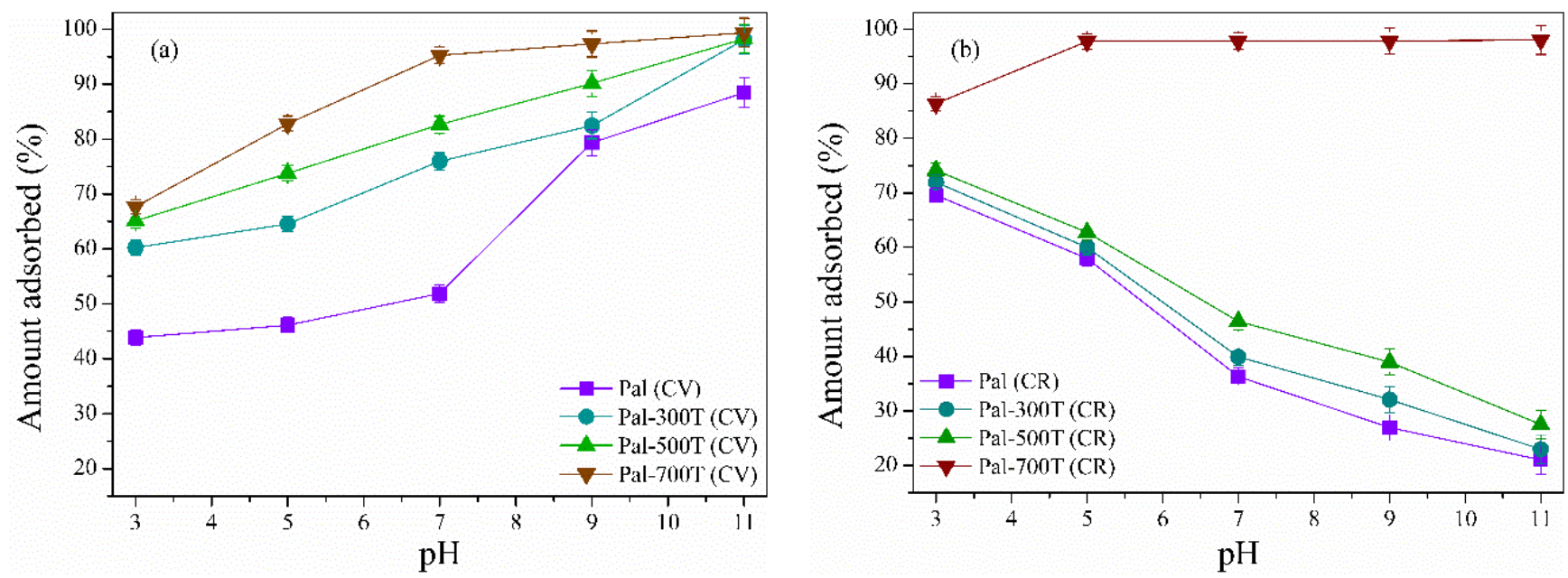

Figure 9. Effect of $\mathrm{pH}$ on the adsorption efficiency of natural and heat-treated palygorskite samples to remove (a) CV and (b) CR.

In a basic medium, the $\mathrm{OH}^{-}$ions promote the deprotonation of the palygorskite surface and generate $-\mathrm{Si}-\mathrm{O}^{-}$groups [110]. Therefore, the electrostatic attraction between the positively charged $\mathrm{CV}$ molecules and the negatively charged adsorbent surface increases, favoring adsorption [111]. In contrast, the negatively charged CR molecules compete with the $\mathrm{OH}^{-}$ions and are also repelled by the negative surface of the adsorbent, which 
decreases the CR dye removal rate [112]. However, the adsorption of CR in the Pal-700T sample is not influenced by the $\mathrm{pH}$ variation, showing a removal greater than $85 \%$ at $\mathrm{pH} 3$ and from $\mathrm{pH} 5$, the removal is greater than $97 \%$.

\subsubsection{Effect of the Amount of Adsorbent}

Different amounts of adsorbents (10-40 mg) were used to adsorption $50 \mathrm{mg} / \mathrm{L}$ of $\mathrm{CV}$ and $\mathrm{CR}$ at $25^{\circ} \mathrm{C}$ for $360 \mathrm{~min}$ at $\mathrm{pH} 7$ (Figure 10a,b). Almost complete removal of CV and CR, both $96 \%$, was observed with $10 \mathrm{mg}$ of Pal-700T; therefore, further increase in adsorbent dosage to $40 \mathrm{mg}$ has little effect on removal percentages. For the other samples, the adsorbed amount increases considerably when the mass of the adsorbent increases from 10 to $40 \mathrm{mg}$; this can be attributed to the increase in the adsorption sites available for the removal of CV and CR $[113,114]$. With $40 \mathrm{mg}$ of adsorbent, the CV removal rate was $82.5 \%, 94.6 \%, 97.1 \%$ and $98 \%$ for Pal, Pal-300T, Pal-500T and Pal-700T, respectively. For CR, the removal rate was $61.1 \%, 62.9 \%, 66.8 \%$ and $98 \%$, for Pal, Pal-300T, Pal-500T and Pal-700T, respectively.
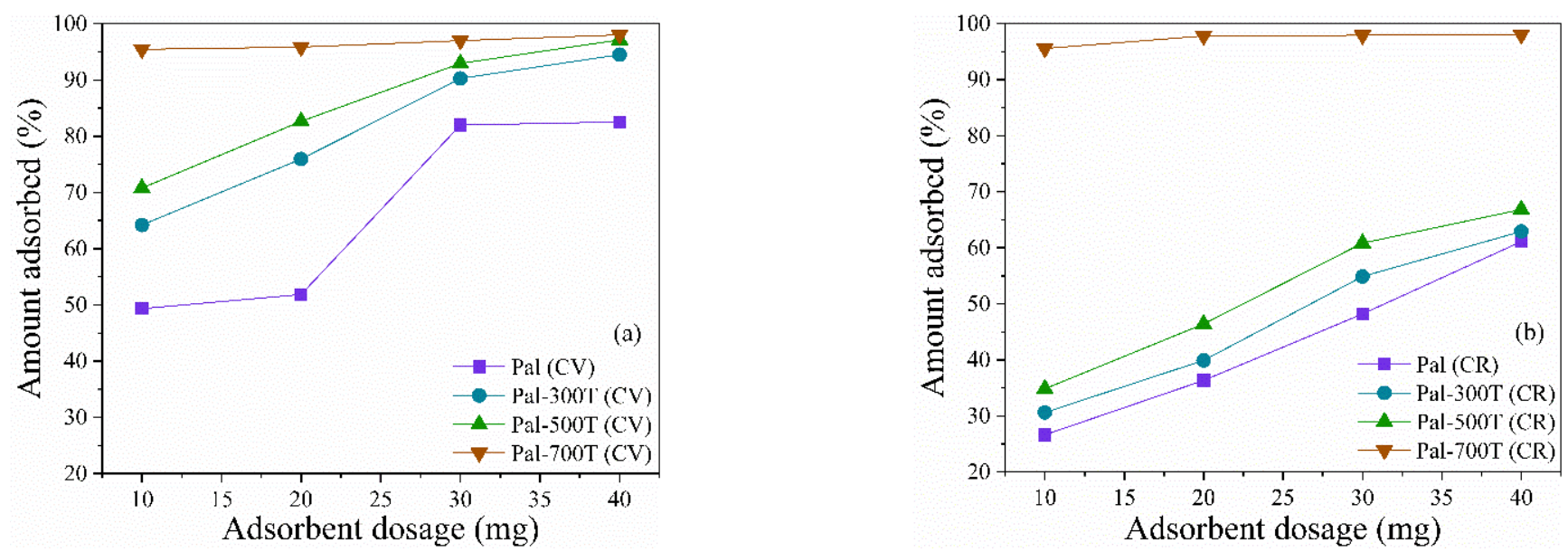

Figure 10. Effect of the amount of adsorbent on the adsorption of (a) CV and (b) CR on palygorskite before and after heat treatment.

\subsection{FTIR before and after Adsorption}

The FTIR spectra of the samples before and after CV and CR adsorption are shown in Figures 11 and 12. Bands at 3612 and $3578 \mathrm{~cm}^{-1}$ were identified in the spectrum of the Pal sample. Such bands are characteristic of clay minerals, the first being attributed to the $\mathrm{Al}-\mathrm{OH}-\mathrm{Al}$ elongation vibration and the second associated with the elongation vibration of the $\mathrm{Al}-\mathrm{Fe}^{3+}-\mathrm{OH}$ or $\mathrm{Al}-\mathrm{Mg}-\mathrm{OH}$ bonds [115-118]. The four bands at 3541, 3374, 3268 and $1656 \mathrm{~cm}^{-1}$ are related to the zeolitic and coordinate waters present in the palygorskite structure $[106,119]$. The characteristic bands of dolomite appear at 1439 and $729 \mathrm{~cm}^{-1}$, related to the asymmetrical elongation of $\mathrm{CO}_{3}$ and the vibrations of $\mathrm{CO}_{3}$, respectively $[120,121]$. This result agrees with the XRD pattern and chemical analysis presented above, which confirm the presence of dolomite. The bands located between 1190 and $975 \mathrm{~cm}^{-1}$ correspond to the elongation of the Si-O bonds. The bands at 1190 and $642 \mathrm{~cm}^{-1}$ refer to the asymmetric and symmetrical stretching of the $\mathrm{Si}-\mathrm{O}-\mathrm{Si}$ bonds, considered fingerprints of the palygorskite [122,123]. The band at $909 \mathrm{~cm}^{-1}$ is related to the dioctahedral character of the palygorskite, being attributed to $\mathrm{Al}-\mathrm{OH}-\mathrm{Al}$ deformation $[124,125]$. The bands at 877 and $580 \mathrm{~cm}^{-1}$ correspond to the flexural vibration mode of the $\mathrm{Al}-\mathrm{Fe}-\mathrm{OH}$ bond [124] and Si-O strain vibration $[123,126]$, respectively. 


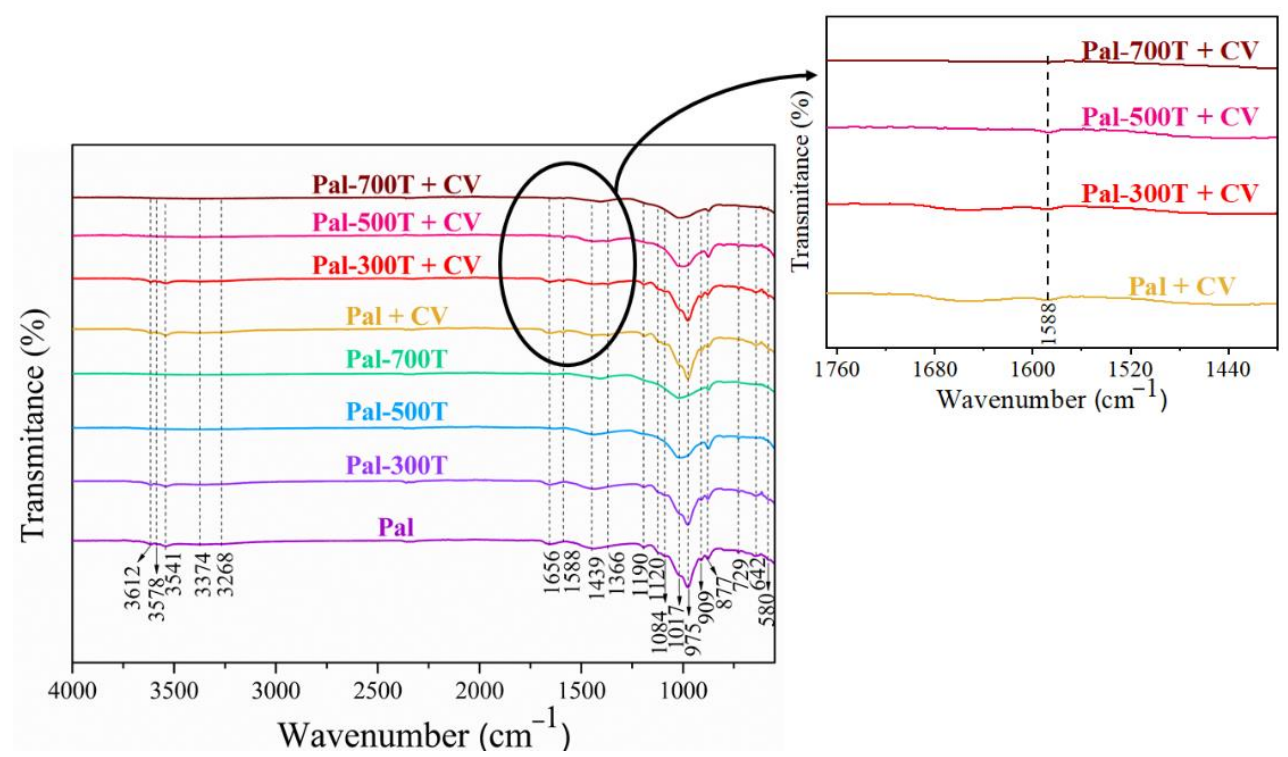

Figure 11. FTIR spectra of samples before and after CV adsorption.

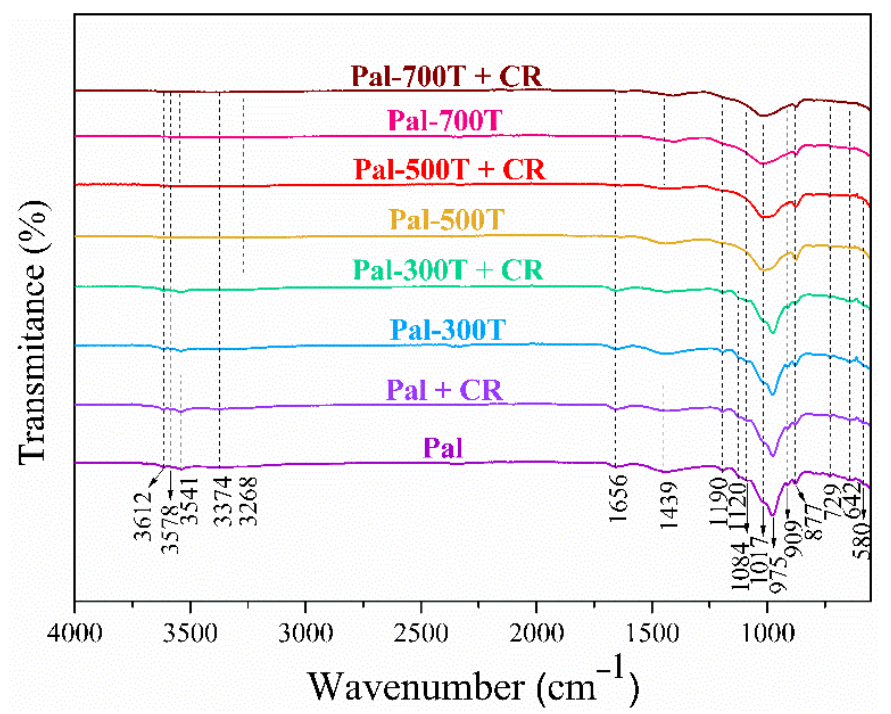

Figure 12. FTIR spectra of samples before and after CR adsorption.

After heat treatment at temperatures above $300{ }^{\circ} \mathrm{C}$, the bands at 3612 and $3578 \mathrm{~cm}^{-1}$ disappeared, due to complete dehydroxylation [86]. The bands related to zeolitic and coordinate water were no longer identified in the spectra of samples calcined above $300{ }^{\circ} \mathrm{C}$, due to losses of zeolitic and coordinate water in the palygorskite structure [54]. The bands located between 1190 and $975 \mathrm{~cm}^{-1}\left(1190\right.$ and $\left.642 \mathrm{~cm}^{-1}\right)$ are considered fingerprints of the palygorskite. Here, due to heat treatment, there was a slight shift in such bands. Above $300{ }^{\circ} \mathrm{C}$, the intensity of these bands decreased, and other bands disappeared. These changes are related to the condensation of silanol and/or aluminol groups via loss of water $[54,72,86]$. The bands at 909 and $580 \mathrm{~cm}^{-1}$ disappeared after heating above $300{ }^{\circ} \mathrm{C}$.

After CV dye adsorption (Figure 11), a new band was detected at $1588 \mathrm{~cm}^{-1}$. This band refers to the $C=C$ elongation vibration of the benzene ring, which is characteristic of the CV dye [127,128]. This band suggests that removing CV dye molecules from the aqueous solution occurred by chemisorption [129]. On the other hand, no new dye-related band was observed after CR dye adsorption (Figure 12). This indicates no break or formation of new bonds after adsorption, suggesting the occurrence of physical adsorption (physisorption) in the adsorption of the CR dye $[18,45]$. 


\subsection{Recyclability Study}

To assess the recyclability of the adsorbents, $60 \mathrm{~mL}$ of ethanol was used to regenerate the adsorption sites. After desorption, the regenerated adsorbent was reused for three cycles and the results are shown in Figure 13a,b. Figure 13a shows the effect of regeneration on the adsorption capacity of samples for $\mathrm{CV}$ removal. After three cycles, the decrease in CV removal efficiency was less than $15 \%$ for all samples, going from $52 \%, 76 \%, 82 \%$ and $96 \%$ to $38 \%, 62 \%, 70 \%$ and $85 \%$ for Pal, Pal-300T, Pal-500T and Pal-700T, respectively. Figure $13 \mathrm{~b}$ shows the effect of regeneration on the adsorption capacity of samples for CR removal. After three cycles, the decrease in CR removal efficiency was also less than $15 \%$ for all samples, going from $36 \%, 40 \%, 46 \%$ and $98 \%$ to $23 \%, 27 \%, 33 \%$ and $86 \%$ for Pal, Pal-300T, Pal-500T and Pal-700T, respectively. The above results indicate that adsorbents derived from palygorskite heat-treated have a good regeneration capacity and can be used repeatedly for the adsorption of $\mathrm{CV}$ and $\mathrm{CR}$ dyes.
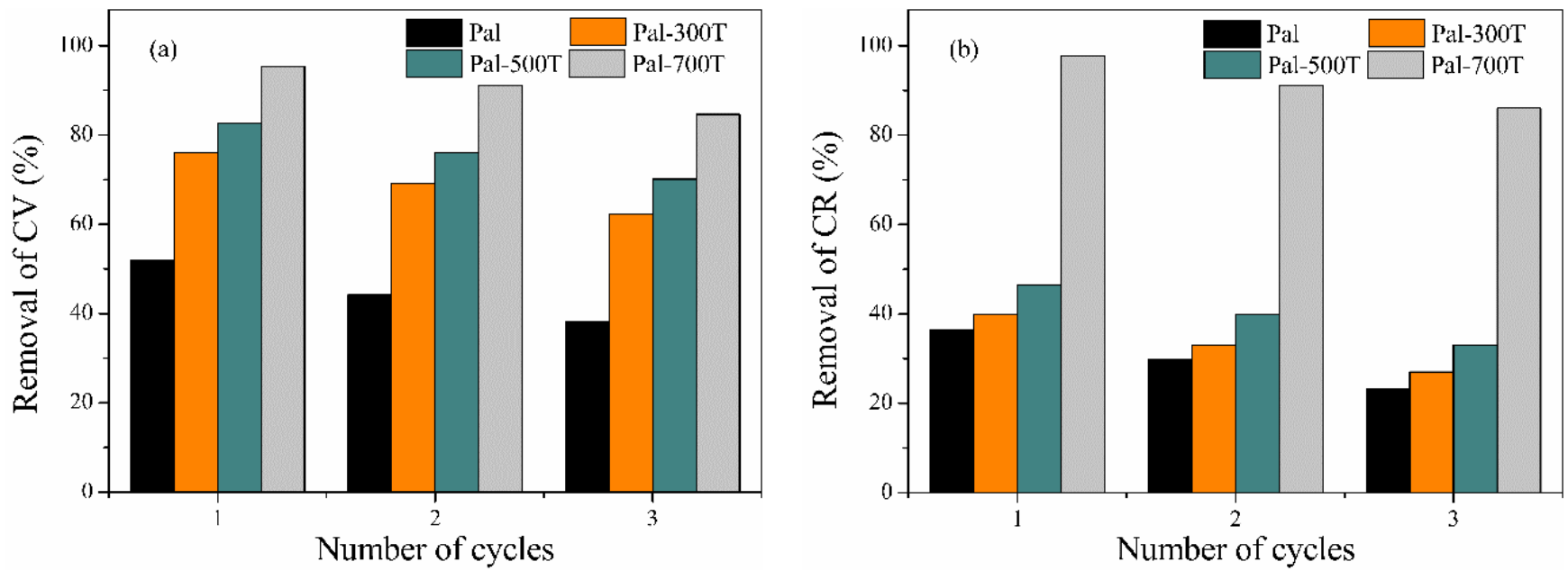

Figure 13. Reusability of palygorskite before and after heat treatment for three cycles to remove the dyes (a) crystal violet and (b) congo red.

\section{Conclusions}

The adsorption of $\mathrm{CV}$ and $\mathrm{CR}$ dyes on natural and calcined palygorskite at different temperatures were successfully investigated. The heat treatment promoted significant changes in the palygorskite structure. At $700{ }^{\circ} \mathrm{C}$, the crystal structure collapsed, resulting in a smaller surface area and the formation of new and larger pores. The heat treatment increased the adsorption capacity of palygorskite. The adsorption kinetic data were better fitted to the Elovich model. The adsorption isotherms of the Pal, Pal-300T and Pal-500T samples fit well with the Freundlich isothermal model, while the Pal-700T isotherms fit better to the Langmuir isothermal model. The Pal-700T sample showed the best adsorptive performance, with a maximum adsorption capacity for CV and CR of $186.5 \mathrm{mg} / \mathrm{g}$ and $144.7 \mathrm{mg} / \mathrm{g}$, respectively. The results revealed that Pal-700T has good adsorption affinity for cationic and anionic dyes. According to the thermodynamic results, the adsorption of $\mathrm{CV}$ and $\mathrm{CR}$ in the samples was spontaneous, favorable, and endothermic. Thus, adsorbents derived from Brazilian palygorskite proved to be promising candidates for the removal of cationic and anionic dyes from water, as they are low cost, non-toxic, ecologically correct and do not require expensive equipment to obtain them.

Author Contributions: Experimental data, data curation, V.C.S., M.E.B.A., M.d.B.C.V., A.M.R. and R.R.M.; conceptualization, funding acquisition and project administration, G.A.N., R.R.M. and J.M.C.; formal analysis and writing-review and editing, V.C.S., R.R.M. and A.M.R. All authors have read and agreed to the published version of the manuscript. 
Funding: This research was funded by the Coordenação de Aperfeiçoamento de Pessoal e Nível Superior-Brasil (CAPES)—Finance Code 001 (scholarship granted to Vanderlane Cavalcanti da Silva), grant number 88882.455338/2019-01.

Institutional Review Board Statement: Not applicable.

Informed Consent Statement: Not applicable.

Data Availability Statement: Not applicable.

Conflicts of Interest: The authors declare no conflict of interest.

\section{References}

1. Reghioua, A.; Barkat, D.; Jawad, A.H.; Abdulhameed, A.S.; Khan, M.R. Synthesis of Schiff's base magnetic crosslinked chitosanglyoxal $/ \mathrm{ZnO} / \mathrm{Fe}_{3} \mathrm{O}_{4}$ nanoparticles for enhanced adsorption of organic dye: Modeling and mechanism study. Sustain. Chem. Pharm. 2021, 20, 100379. [CrossRef]

2. Eltaweil, A.S.; Elgarhy, G.S.; El-Subruiti, G.M.; Omer, A.M. Carboxymethyl cellulose/carboxylated graphene oxide composite microbeads for efficient adsorption of cationic methylene blue dye. Int. J. Biol. Macromol. 2020, 154, 307-318. [CrossRef] [PubMed]

3. Mirza, A.; Ahmad, R. An efficient sequestration of toxic crystal violet dye from aqueous solution by Alginate/Pectin nanocomposite: A novel and ecofriendly adsorbent. Groundw. Sustain. Dev. 2020, 11, 100373. [CrossRef]

4. Tyagi, U. Adsorption of dyes using activated carbon derived from pyrolysis of vetiveria zizanioides in a fixed bed reactor. Groundw. Sustain. Dev. 2020, 10, 100303. [CrossRef]

5. Zhao, J.; Xu, L.; Su, Y.; Yu, H.; Liu, H.; Qian, S.; Zheng, W.; Zhao, Y. Zr-MOFs loaded on polyurethane foam by polydopamine for enhanced dye adsorption. J. Environ. Sci. 2021, 101, 177-188. [CrossRef]

6. $\quad$ El Malah, T.; Nour, H.F.; Radwan, E.K.; Abdel Mageid, R.E.; Khattab, T.A.; Olson, M.A. A bipyridinium-based polyhydrazone adsorbent that exhibits ultrahigh adsorption capacity for the anionic azo dye, direct blue 71. Chem. Eng. J. 2021, $409,128195$. [CrossRef]

7. He, T.; Hua, J.; Chen, R.; Yu, L. Adsorption characteristics of methylene blue by a dye-degrading and extracellular polymeric substance -producing strain. J. Environ. Manag. 2021, 288, 112446. [CrossRef]

8. Mohanty, S.; Moulick, S.; Maji, S.K. Adsorption/photodegradation of crystal violet (basic dye) from aqueous solution by hydrothermally synthesized titanate nanotube (TNT). J. Water Process Eng. 2020, 37, 101428. [CrossRef]

9. Uddin, M.K.; Mashkoor, F.; AlArifi, I.M.; Nasar, A. Simple one-step synthesis process of novel MoS $_{2} @$ bentonite magnetic nanocomposite for efficient adsorption of crystal violet from aqueous solution. Mater. Res. Bull. 2021, 139, 111279. [CrossRef]

10. Ebrahimpour, M.; Hassaninejad-Darzi, S.K.; Zavvar Mousavi, H. Adsorption of ternary toxic crystal violet, malachite green and methylene blue onto synthesised SBA-15 mesoporous nanoparticles. Int. J. Environ. Anal. Chem. 2020, 1-24. [CrossRef]

11. Pang, X.; Sellaoui, L.; Franco, D.; Dotto, G.L.; Georgin, J.; Bajahzar, A.; Belmabrouk, H.; Lamine, A.B.; Bonilla-Petriciolet, A.; Li, Z Adsorption of crystal violet on biomasses from pecan nutshell, para chestnut husk, araucaria bark and palm cactus: Experimental study and theoretical modeling via monolayer and double layer statistical physics models. Chem. Eng. J. 2019, $378,122101$. [CrossRef]

12. Chahinez, H.-O.; Abdelkader, O.; Leila, Y.; Tran, H.N. One-stage preparation of palm petiole-derived biochar: Characterization and application for adsorption of crystal violet dye in water. Environ. Technol. Innov. 2020, 19, 100872. [CrossRef]

13. Ciobanu, G.; Harja, M.; Diaconu, M.; Cimpeanu, C.; Teodorescu, R.; Bucur, D. Crystal violet dye removal from aqueous solution by nanohydroxyapatite. J. Food Agric. Environ. 2014, 12, 499-502.

14. Mani, S.; Bharagava, R.N. Exposure to crystal violet, its toxic, genotoxic and carcinogenic effects on environment and its degradation and detoxification for environmental safety. In Reviews of Environmental Contamination and Toxicology; Springer: Berlin, Germany, 2016; Volume 237, pp. 71-104.

15. Kulkarni, M.R.; Revanth, T.; Acharya, A.; Bhat, P. Removal of Crystal Violet dye from aqueous solution using water hyacinth: Equilibrium, kinetics and thermodynamics study. Resour. Technol. 2017, 3, 71-77. [CrossRef]

16. Pashaei-Fakhri, S.; Peighambardoust, S.J.; Foroutan, R.; Arsalani, N.; Ramavandi, B. Crystal violet dye sorption over acrylamide/graphene oxide bonded sodium alginate nanocomposite hydrogel. Chemosphere 2021, 270, 129419. [CrossRef]

17. Abbasi, F.; Tavakkoli Yaraki, M.; Farrokhnia, A.; Bamdad, M. Keratin nanoparticles obtained from human hair for removal of crystal violet from aqueous solution: Optimized by Taguchi method. Int. J. Biol. Macromol. 2020, 143, 492-500. [CrossRef] [PubMed]

18. Li, Z.; Hanafy, H.; Zhang, L.; Sellaoui, L.; Netto, M.S.; Oliveira, M.L.S.; Seliem, M.K.; Dotto, G.L.; Bonilla-Petriciolet, A.; Li, Q. Adsorption of congo red and methylene blue dyes on an ashitaba waste and a walnut shell-based activated carbon from aqueous solutions: Experiments, characterization and physical interpretations. Chem. Eng. J. 2020, 388, 124263. [CrossRef]

19. Gupta, V.K.; Agarwal, S.; Ahmad, R.; Mirza, A.; Mittal, J. Sequestration of toxic congo red dye from aqueous solution using ecofriendly guar gum/activated carbon nanocomposite. Int. J. Biol. Macromol. 2020, 158, 1310-1318. [CrossRef] [PubMed]

20. Wekoye, J.N.; Wanyonyi, W.C.; Wangila, P.T.; Tonui, M.K. Kinetic and equilibrium studies of Congo red dye adsorption on cabbage waste powder. Environ. Chem. Ecotoxicol. 2020, 2, 24-31. [CrossRef] 
21. Borth, K.W.; Galdino, C.W.; de Carvalho Teixeira, V.; Anaissi, F.J. Iron oxide nanoparticles obtained from steel waste recycling as a green alternative for Congo red dye fast adsorption. Appl. Surf. Sci. 2021, 546, 149126. [CrossRef]

22. Zheng, Y.; Cheng, B.; Fan, J.; Yu, J.; Ho, W. Review on nickel-based adsorption materials for Congo red. J. Hazard. Mater. 2021, 403, 123559. [CrossRef] [PubMed]

23. Miandad, R.; Kumar, R.; Barakat, M.A.; Basheer, C.; Aburiazaiza, A.S.; Nizami, A.S.; Rehan, M. Untapped conversion of plastic waste char into carbon-metal LDOs for the adsorption of Congo red. J. Colloid Interface Sci. 2018, 511, 402-410. [CrossRef]

24. Nodehi, R.; Shayesteh, H.; Kelishami, A.R. Enhanced adsorption of congo red using cationic surfactant functionalized zeolite particles. Microchem. J. 2020, 153, 104281. [CrossRef]

25. Prajapati, A.K.; Mondal, M.K. Novel green strategy for CuO-ZnO-C nanocomposites fabrication using marigold (Tagetes spp.) flower petals extract with and without CTAB treatment for adsorption of $\mathrm{Cr}(\mathrm{VI})$ and Congo red dye. J. Environ. Manag. 2021, 290, 112615. [CrossRef] [PubMed]

26. Valadi, F.M.; Ekramipooya, A.; Gholami, M.R. Selective separation of Congo Red from a mixture of anionic and cationic dyes using magnetic-MOF: Experimental and DFT study. J. Mol. Liq. 2020, 318, 114051. [CrossRef]

27. Zhang, Q.; Yan, Z.; Ouyang, J.; Zhang, Y.; Yang, H.; Chen, D. Chemically modified kaolinite nanolayers for the removal of organic pollutants. Appl. Clay Sci. 2018, 157, 283-290. [CrossRef]

28. Kirankumar, V.S.; Sumathi, S. Copper and cerium co-doped cobalt ferrite nanoparticles: Structural, morphological, optical, magnetic, and photocatalytic properties. Environ. Sci. Pollut. Res. 2019, 26, 19189-19206. [CrossRef]

29. Olusegun, S.J.; Mohallem, N.D.S. Comparative adsorption mechanism of doxycycline and Congo red using synthesized kaolinite supported CoFe2O4 nanoparticles. Environ. Pollut. 2020, 260, 114019. [CrossRef]

30. Elella, M.H.A.; Sabaa, M.W.; Abd ElHafeez, E.; Mohamed, R.R. Crystal violet dye removal using crosslinked grafted xanthan gum. Int. J. Biol. Macromol. 2019, 137, 1086-1101. [CrossRef]

31. Ain, Q.U.; Zhang, H.; Yaseen, M.; Rasheed, U.; Liu, K.; Subhan, S.; Tong, Z. Facile fabrication of hydroxyapatite-magnetitebentonite composite for efficient adsorption of $\mathrm{Pb}$ (II), Cd (II), and crystal violet from aqueous solution. J. Clean. Prod. 2020, 247, 119088. [CrossRef]

32. Sathiyavimal, S.; Vasantharaj, S.; Shanmugavel, M.; Manikandan, E.; Nguyen-Tri, P.; Brindhadevi, K.; Pugazhendhi, A. Facile synthesis and characterization of hydroxyapatite from fish bones: Photocatalytic degradation of industrial dyes (crystal violet and Congo red). Prog. Org. Coatings 2020, 148, 105890. [CrossRef]

33. An, S.; Liu, X.; Yang, L.; Zhang, L. Enhancement removal of crystal violet dye using magnetic calcium ferrite nanoparticle: Study in single- and binary-solute systems. Chem. Eng. Res. Des. 2015, 94, 726-735. [CrossRef]

34. Dotto, J.; Fagundes-Klen, M.R.; Veit, M.T.; Palácio, S.M.; Bergamasco, R. Performance of different coagulants in the coagulation/flocculation process of textile wastewater. J. Clean. Prod. 2019, 208, 656-665. [CrossRef]

35. Joseph, J.; Radhakrishnan, R.C.; Johnson, J.K.; Joy, S.P.; Thomas, J. Ion-exchange mediated removal of cationic dye-stuffs from water using ammonium phosphomolybdate. Mater. Chem. Phys. 2020, 242, 122488. [CrossRef]

36. Zhijiang, C.; Ping, X.; Cong, Z.; Tingting, Z.; Jie, G.; Kongyin, Z. Preparation and characterization of a bi-layered nano-filtration membrane from a chitosan hydrogel and bacterial cellulose nanofiber for dye removal. Cellulose 2018, 25, 5123-5137. [CrossRef]

37. Hao, N.; Nie, Y.; Xu, Z.; Jin, C.; Fyda, T.J.; Zhang, J.X.J. Microfluidics-enabled acceleration of Fenton oxidation for degradation of organic dyes with rod-like zero-valent iron nanoassemblies. J. Colloid Interface Sci. 2020, 559, 254-262. [CrossRef]

38. Pereira, L.A.; Couto, A.B.; Almeida, D.A.L.; Ferreira, N.G. Singular properties of boron-doped diamond/carbon fiber composite as anode in Brilliant Green dye electrochemical degradation. Diam. Relat. Mater. 2020, 103, 107708. [CrossRef]

39. Achour, Y.; Bahsis, L.; Ablouh, E.-H.; Yazid, H.; Laamari, M.R.; Haddad, M. El Insight into adsorption mechanism of Congo red dye onto Bombax Buonopozense bark Activated-carbon using Central composite design and DFT studies. Surf. Interfaces 2021, 23, 100977. [CrossRef]

40. Bensalah, H.; Younssi, S.A.; Ouammou, M.; Gurlo, A.; Bekheet, M.F. Azo dye adsorption on an industrial waste-transformed hydroxyapatite adsorbent: Kinetics, isotherms, mechanism and regeneration studies. J. Environ. Chem. Eng. 2020, 8, 103807. [CrossRef]

41. Ji, Y.; Xu, F.; Wei, W.; Gao, H.; Zhang, K.; Zhang, G.; Xu, Y.; Zhang, P. Efficient and fast adsorption of methylene blue dye onto a nanosheet MFI zeolite. J. Solid State Chem. 2021, 295, 121917. [CrossRef]

42. Khnifira, M.; Boumya, W.; Abdennouri, M.; Sadiq, M.; Achak, M.; Serdaroğlu, G.; Kaya, S.; Şimşek, S.; Barka, N. A combined molecular dynamic simulation, DFT calculations, and experimental study of the eriochrome black T dye adsorption onto chitosan in aqueous solutions. Int. J. Biol. Macromol. 2021, 166, 707-721. [CrossRef] [PubMed]

43. Jiang, H.-L.; Xu, M.-Y.; Xie, Z.-W.; Hai, W.; Xie, X.-L.; He, F.-A. Selective adsorption of anionic dyes from aqueous solution by a novel $\beta$-cyclodextrin-based polymer. J. Mol. Struct. 2020, 1203, 127373. [CrossRef]

44. Zhu, J.; Zhang, P.; Wang, Y.; Wen, K.; Su, X.; Zhu, R.; He, H.; Xi, Y. Effect of acid activation of palygorskite on their toluene adsorption behaviors. Appl. Clay Sci. 2018, 159, 60-67. [CrossRef]

45. Silva, V.C.; Araújo, M.E.B.; Rodrigues, A.M.; Cartaxo, J.M.; Menezes, R.R.; Neves, G.A. Adsorption Behavior of Acid-Treated Brazilian Palygorskite for Cationic and Anionic Dyes Removal from the Water. Sustainability 2021, 13, 3954. [CrossRef]

46. El Berrichi, F.Z.; Ayari, F. Kaolin-issued zeolite A as efficient adsorbent for Bezanyl Yellow and Nylomine Green anionic dyes. Microporous Mesoporous Mater. 2017, 243, 91-101. 
47. Chaari, I.; Medhioub, M.; Jamoussi, F.; Hamzaoui, A.H. Acid-treated clay materials (Southwestern Tunisia) for removing sodium leuco-vat dye: Characterization, adsorption study and activation mechanism. J. Mol. Struct. 2021, 1223, 128944. [CrossRef]

48. Zhang, P.; O'Connor, D.; Wang, Y.; Jiang, L.; Xia, T.; Wang, L.; Tsang, D.C.W.; Ok, Y.S.; Hou, D. A green biochar/iron oxide composite for methylene blue removal. J. Hazard. Mater. 2020, 384, 121286. [CrossRef] [PubMed]

49. Azha, S.F.; Sellaoui, L.; Yunus, E.H.E.; Yee, C.J.; Bonilla-Petriciolet, A.; Lamine, A.B.; Ismail, S. Iron-modified composite adsorbent coating for azo dye removal and its regeneration by photo-Fenton process: Synthesis, characterization and adsorption mechanism interpretation. Chem. Eng. J. 2019, 361, 31-40. [CrossRef]

50. Yang, R.; Li, D.; Li, A.; Yang, H. Adsorption properties and mechanisms of palygorskite for removal of various ionic dyes from water. Appl. Clay Sci. 2018, 151, 20-28. [CrossRef]

51. Piri, F.; Mollahosseini, A.; Hosseini, M.M. Enhanced adsorption of dyes on microwave-assisted synthesized magnetic zeolitehydroxyapatite nanocomposite. J. Environ. Chem. Eng. 2019, 7, 103338. [CrossRef]

52. Xinguo, X.; Jiling, Z.; Ruiyu, J.; Qi, X. Application of Modified Attapulgite Clay as the Adsorbent in Gasoline Desulfurization. China Pet. Process. Petrochemical Technol. 2014, 16, 63-68.

53. Wang, W.; Tian, G.; Zhang, Z.; Wang, A. A simple hydrothermal approach to modify palygorskite for high-efficient adsorption of methylene blue and Cu (II) ions. Chem. Eng. J. 2015, 265, 228-238. [CrossRef]

54. Câmara, A.B.F.; Sales, R.V.; Bertolino, L.C.; Furlanetto, R.P.P.; Rodríguez-Castellón, E.; De Carvalho, L.S. Novel application for palygorskite clay mineral: A kinetic and thermodynamic assessment of diesel fuel desulfurization. Adsorption 2020, 26, 267-282. [CrossRef]

55. de Souza, C.G.; de Jesus, T.C.L.; dos Santos, R.C.; Bomfim, L.M.; Bertolino, L.C.; de Andrade, D.F.; Spinelli, L.S. Characterization of Brazilian palygorskite (Guadalupe region) and adsorptive behaviour for solvatochromic dyes. Clay Miner. 2021, 1-10. [CrossRef]

56. Wei, Y.; Guo, K.; Wu, H.; Yuan, P.; Liu, D.; Du, P.; Chen, P.; Wei, L.; Chen, W. Highly regenerative and efficient adsorption of phosphate by restructuring natural palygorskite clay via alkaline activation and co-calcination. Chem. Commun. 2021, 57, 1639-1642. [CrossRef]

57. Kotti, M.; Papafilippaki, A.; Prassa, P.; Xirouhaki, A. Removal of Cationic Surfactants from Water by Adsorption on Attapulgite. Comput. Water Energy Environ. Eng. 2018, 7, 111. [CrossRef]

58. Li, J.; Zheng, Y.; Feng, X.; Lv, C.; Liu, X.; Zhao, Y.; Chen, L. Adsorption removal of Ni (II) and phenol from aqueous solution by modified attapulgite and its composite hydrogel. Environ. Technol. 2019, 1-15. [CrossRef]

59. Zhdanyuk, N.V. Adsorption of Cr (VI) and Co (II) by palygorskite modified with cationic surfactants. Вісник Одеського національного університету. Хімія 2017, 22, 73-81. [CrossRef]

60. Chen, H.; Zhao, J.; Zhong, A.; Jin, Y. Removal capacity and adsorption mechanism of heat-treated palygorskite clay for methylene blue. Chem. Eng. J. 2011, 174, 143-150. [CrossRef]

61. Gan, F.; Zhou, J.; Wang, H.; Du, C.; Chen, X. Removal of phosphate from aqueous solution by thermally treated natural palygorskite. Water Res. 2009, 43, 2907-2915. [CrossRef]

62. Chen, H.; Zhao, Y.; Wang, A. Removal of $\mathrm{Cu}$ (II) from aqueous solution by adsorption onto acid-activated palygorskite. J. Hazard. Mater. 2007, 149, 346-354. [CrossRef]

63. da Costa, F.P.; da Silva Morais, C.R.; Pinto, H.C.; Rodrigues, A.M. Microstructure and physico-mechanical properties of $\mathrm{Al}_{2} \mathrm{O}_{3}-$ doped sustainable glass-ceramic foams. Mater. Chem. Phys. 2020, 256, 123612. [CrossRef]

64. Pereira da Costa, F.; Rodrigues da Silva Morais, C.; Rodrigues, A.M. Sustainable glass-ceramic foams manufactured from waste glass bottles and bentonite. Ceram. Int. 2020, 46, 17957-17961. [CrossRef]

65. da Silva, A.L.; Luna, C.B.B.; de Farias, A.F.F.; de Medeiros, S.A.S.L.; Meneghetti, S.M.P.; Rodrigues, A.M.; Costa, A.C.F.D.M. From Disposal to Reuse: Production of Sustainable Fatty Acid Alkyl Esters Derived from Residual Oil Using a Biphasic Magnetic Catalyst. Sustainability 2020, 12, 10159. [CrossRef]

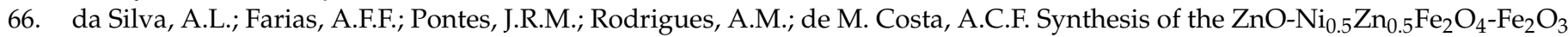
magnetic catalyst in pilot-scale by combustion reaction and its application on the biodiesel production process from oil residual. Arab. J. Chem. 2020, 13, 7665-7679. [CrossRef]

67. Dong, W.; Lu, Y.; Wang, W.; Zhang, M.; Jing, Y.; Wang, A. A sustainable approach to fabricate new 1D and 2D nanomaterials from natural abundant palygorskite clay for antibacterial and adsorption. Chem. Eng. J. 2020, 382, 122984. [CrossRef]

68. Ryan, B.H.; Kaczmarek, S.E.; Rivers, J.M. Dolomite dissolution: An alternative diagenetic pathway for the formation of palygorskite clay. Sedimentology 2019, 66, 1803-1824. [CrossRef]

69. Bu, X.; Zhang, G.; Guo, Y. Thermal modified palygorskite: Preparation, characterization, and application for cationic dyecontaining wastewater purification. Desalin. Water Treat. 2011, 30, 339-347. [CrossRef]

70. Zeng, H.F.; Lin, L.J.; Xi, Y.M.; Han, Z.Y. Effects of raw and heated palygorskite on rumen fermentation in vitro. Appl. Clay Sci. 2017, 138, 125-130. [CrossRef]

71. Biswas, B.; Sarkar, B.; Naidu, R. Bacterial mineralization of phenanthrene on thermally activated palygorskite: A $14 \mathrm{C}$ radiotracer study. Sci. Total Environ. 2017, 579, 709-717. [CrossRef]

72. Xavier, K.C.M.; Santos, M.S.F.; Osajima, J.A.; Luz, A.B.; Fonseca, M.G.; Silva Filho, E.C. Thermally activated palygorskites as agents to clarify soybean oil. Appl. Clay Sci. 2016, 119, 338-347. [CrossRef]

73. Wang, K.; Wang, L.; Zhang, Y.; Zhang, Y.; Liang, J. Microstructural evolution and sintering properties of palygorskite nanofibers. Int. J. Appl. Ceram. Technol. 2020, 17, 1833-1842. [CrossRef] 
74. Yan, W.; Liu, D.; Tan, D.; Yuan, P.; Chen, M. FTIR spectroscopy study of the structure changes of palygorskite under heating. Spectrochim. Acta Part A Mol. Biomol. Spectrosc. 2012, 97, 1052-1057. [CrossRef] [PubMed]

75. Galai, H.; Pijolat, M.; Nahdi, K.; Trabelsi-Ayadi, M. Mechanism of growth of $\mathrm{MgO}$ and $\mathrm{CaCO}_{3}$ during a dolomite partial decomposition. Solid State Ion. 2007, 178, 1039-1047. [CrossRef]

76. Rat'ko, A.I.; Ivanets, A.I.; Kulak, A.I.; Morozov, E.A.; Sakhar, I.O. Thermal decomposition of natural dolomite. Inorg. Mater. 2011, 47, 1372-1377. [CrossRef]

77. Lin, S.; Zhou, T.; Yin, S. Properties of thermally treated granular montmorillonite-palygorskite adsorbent (GMPA) and use to remove $\mathrm{Pb}^{2+}$ and $\mathrm{Cu}^{2+}$ from aqueous solutions. Clays Clay Miner. 2017, 65, 184-192. [CrossRef]

78. Wang, Y.; Shen, Y.; Qin, Z.; Li, S.; Zhang, T. Preparation of three-dimensional palygorskite based carrier. MethodsX 2020, 7, 100815. [CrossRef] [PubMed]

79. Frinisrasra, N.; Srasra, E. Effect of heating on palygorskite and acid treated palygorskite properties. Электроннаяобработка материалов 2008, 44, 43-49.

80. Ogorodova, L.; Vigasina, M.; Melchakova, L.; Krupskaya, V.; Kiseleva, I. Thermochemical study of natural magnesium aluminum phyllosilicate: Palygorskite. J. Chem. Thermodyn. 2015, 89, 205-211. [CrossRef]

81. Bayram, H.; Önal, M.; Üstünışık, G.; Sarıkaya, Y. Some thermal characteristics of a mineral mixture of palygorskite, metahalloysite, magnesite and dolomite. J. Therm. Anal. Calorim. 2007, 89, 169-174. [CrossRef]

82. Amorim, K.B.; Angélica, R.S. Mineralogy and geochemistry of occurrence of palygorskite of Alcântara, S. Luís-Grajaú basin, Maranhão, Brazil. Cerâmica 2011, 57, 483-490. [CrossRef]

83. Bouna, L.; Rhouta, B.; Amjoud, M.; Maury, F.; Lafont, M.-C.; Jada, A.; Senocq, F.; Daoudi, L. Synthesis, characterization and photocatalytic activity of $\mathrm{TiO}_{2}$ supported natural palygorskite microfibers. Appl. Clay Sci. 2011, 52, 301-311. [CrossRef]

84. Kadir, S.; Eren, M.; Atabey, E. Dolocretes and associated palygorskite occurrences in siliciclastic red mudstones of the Sariyer formation (Middle Miocene), southeastern side of the Çanakkale strait, Turkey. Clays Clay Miner. 2010, 58, 205-219. [CrossRef]

85. Chen, T.; Wang, J.; Qing, C.; Peng, S.; Song, Y.; Guo, Y. Effect of heat treatment on structure, morphology and surface properties of palygorskite. J. -Chin. Ceram. Soc. 2006, 34, 1406.

86. Boudriche, L.; Calvet, R.; Hamdi, B.; Balard, H. Surface properties evolution of attapulgite by IGC analysis as a function of thermal treatment. Colloids Surf. A Physicochem. Eng. Asp. 2012, 399, 1-10. [CrossRef]

87. Pathania, D.; Sharma, S.; Singh, P. Removal of methylene blue by adsorption onto activated carbon developed from Ficus carica bast. Arab. J. Chem. 2017, 10, S1445-S1451. [CrossRef]

88. Tang, J.; Mu, B.; Zong, L.; Wang, A. From waste hot-pot oil as carbon precursor to development of recyclable attapulgite/carbon composites for wastewater treatment. J. Environ. Sci. 2019, 75, 346-358. [CrossRef] [PubMed]

89. Fernandes, J.V.; Rodrigues, A.M.; Menezes, R.R.; Neves, G.D.A. Adsorption of Anionic Dye on the Acid-Functionalized Bentonite. Materials 2020, 13, 3600. [CrossRef]

90. Nebaghe, K.C.; El Boundati, Y.; Ziat, K.; Naji, A.; Rghioui, L.; Saidi, M. Comparison of linear and non-linear method for determination of optimum equilibrium isotherm for adsorption of copper (II) onto treated Martil sand. Fluid Phase Equilib. 2016, 430, 188-194. [CrossRef]

91. Garba, Z.N. The Relevance of Isotherm and Kinetic Models to Chlorophenols Adsorption: A Review. Avicenna J. Environ. Heal. Eng. 2019, 6, 55-65. [CrossRef]

92. Tang, H.; Li, W.; Zhang, T.; Li, Q.; Xing, J.; Liu, H. Improvement in diesel desulfurization capacity by equilibrium isotherms analysis. Sep. Purif. Technol. 2011, 78, 352-356. [CrossRef]

93. Sahu, S.; Pahi, S.; Tripathy, S.; Singh, S.K.; Behera, A.; Sahu, U.K.; Patel, R.K. Adsorption of methylene blue on chemically modified lychee seed biochar: Dynamic, equilibrium, and thermodynamic study. J. Mol. Liq. 2020, 315, 113743. [CrossRef]

94. Aljeboree, A.M.; Alshirifi, A.N.; Alkaim, A.F. Kinetics and equilibrium study for the adsorption of textile dyes on coconut shell activated carbon. Arab. J. Chem. 2017, 10, S3381-S3393. [CrossRef]

95. Shigaki, N.; Mogi, Y.; Haraoka, T.; Furuya, E. Measurements and calculations of the equilibrium adsorption amounts of $\mathrm{CO}_{2}-\mathrm{N}_{2}$, $\mathrm{CO}-\mathrm{N}_{2}$, and $\mathrm{CO}_{2}-\mathrm{CO}$ mixed gases on $13 \mathrm{X}$ zeolite. SN Appl. Sci. 2020, 2, 488. [CrossRef]

96. Kaur, S.; Rani, S.; Mahajan, R.K. Adsorption kinetics for the removal of hazardous dye congo red by biowaste materials as adsorbents. J. Chem. 2013, 2013. [CrossRef]

97. Litefti, K.; Freire, M.S.; Stitou, M.; González-Álvarez, J. Adsorption of an anionic dye (Congo red) from aqueous solutions by pine bark. Sci. Rep. 2019, 9, 16530. [CrossRef]

98. Al-Futaisi, A.; Jamrah, A.; Al-Hanai, R. Aspects of cationic dye molecule adsorption to palygorskite. Desalination 2007, 214, 327-342. [CrossRef]

99. Liu, M.; Zang, Z.; Zhang, S.; Ouyang, G.; Han, R. Enhanced fluoride adsorption from aqueous solution by zirconium (IV)impregnated magnetic chitosan graphene oxide. Int. J. Biol. Macromol. 2021, 182, 1759-1768. [CrossRef]

100. Chen, L.; Zhu, Y.; Cui, Y.; Dai, R.; Shan, Z.; Chen, H. Fabrication of starch-based high-performance adsorptive hydrogels using a novel effective pretreatment and adsorption for cationic methylene blue dye: Behavior and mechanism. Chem. Eng. J. 2021, 405, 126953. [CrossRef]

101. Keerthanan, S.; Bhatnagar, A.; Mahatantila, K.; Jayasinghe, C.; Ok, Y.S.; Vithanage, M. Engineered tea-waste biochar for the removal of caffeine, a model compound in pharmaceuticals and personal care products (PPCPs), from aqueous media. Environ. Technol. Innov. 2020, 19, 100847. [CrossRef] 
102. Ashiq, A.; Adassooriya, N.M.; Sarkar, B.; Rajapaksha, A.U.; Ok, Y.S.; Vithanage, M. Municipal solid waste biochar-bentonite composite for the removal of antibiotic ciprofloxacin from aqueous media. J. Environ. Manag. 2019, 236, 428-435. [CrossRef]

103. Romdhane, D.F.; Satlaoui, Y.; Nasraoui, R.; Charef, A.; Azouzi, R. Adsorption, modeling, thermodynamic, and kinetic studies of methyl red removal from textile-polluted water using natural and purified organic matter rich clays as low-cost adsorbent. J. Chem. 2020, 2020, 4376173. [CrossRef]

104. Sevim, F.; Lacin, O.; Ediz, E.F.; Demir, F. Adsorption capacity, isotherm, kinetic, and thermodynamic studies on adsorption behavior of malachite green onto natural red clay. Environ. Prog. Sustain. Energy 2021, 40, e13471. [CrossRef]

105. Hasanzadeh, M.; Simchi, A.; Far, H.S. Nanoporous composites of activated carbon-metal organic frameworks for organic dye adsorption: Synthesis, adsorption mechanism and kinetics studies. J. Ind. Eng. Chem. 2020, 81, 405-414. [CrossRef]

106. Youcef, L.D.; Belaroui, L.S.; López-Galindo, A. Adsorption of a cationic methylene blue dye on an Algerian palygorskite. Appl. Clay Sci. 2019, 179, 105145. [CrossRef]

107. Jain, S.N.; Tamboli, S.R.; Sutar, D.S.; Jadhav, S.R.; Marathe, J.V.; Shaikh, A.A.; Prajapati, A.A. Batch and continuous studies for adsorption of anionic dye onto waste tea residue: Kinetic, equilibrium, breakthrough and reusability studies. J. Clean. Prod. 2020, 252, 119778. [CrossRef]

108. Mittal, H.; Al Alili, A.; Morajkar, P.P.; Alhassan, S.M. Graphene oxide crosslinked hydrogel nanocomposites of xanthan gum for the adsorption of crystal violet dye. J. Mol. Liq. 2021, 323, 115034. [CrossRef]

109. Dong, W.; Lu, Y.; Wang, W.; Zong, L.; Zhu, Y.; Kang, Y.; Wang, A. A new route to fabricate high-efficient porous silicate adsorbents by simultaneous inorganic-organic functionalization of low-grade palygorskite clay for removal of Congo red. Microporous Mesoporous Mater. 2019, 277, 267-276. [CrossRef]

110. Sousa, H.R.; Silva, L.S.; Sousa, P.A.A.; Sousa, R.R.M.; Fonseca, M.G.; Osajima, J.A.; Silva-Filho, E.C. Evaluation of methylene blue removal by plasma activated palygorskites. J. Mater. Res. Technol. 2019, 8, 5432-5442. [CrossRef]

111. Omer, A.M.; Elgarhy, G.S.; El-Subruiti, G.M.; Khalifa, R.E.; Eltaweil, A.S. Fabrication of novel iminodiacetic acid-functionalized carboxymethyl cellulose microbeads for efficient removal of cationic crystal violet dye from aqueous solutions. Int. J. Biol. Macromol. 2020, 148, 1072-1083. [CrossRef]

112. Zhang, S.; Zhong, L.; Yang, H.; Tang, A.; Zuo, X. Magnetic carbon-coated palygorskite loaded with cobalt nanoparticles for Congo Red removal from waters. Appl. Clay Sci. 2020, 198, 105856. [CrossRef]

113. Huang, D.; Zheng, Y.; Zhang, Z.; Quan, Q.; Qiang, X. Synergistic effect of hydrophilic palygorskite and hydrophobic zein particles on the properties of chitosan films. Mater. Des. 2020, 185, 108229. [CrossRef]

114. Wong, S.; Abd Ghafar, N.; Ngadi, N.; Razmi, F.A.; Inuwa, I.M.; Mat, R.; Amin, N.A.S. Effective removal of anionic textile dyes using adsorbent synthesized from coffee waste. Sci. Rep. 2020, 10, 2928. [CrossRef]

115. Madejova, J.; Komadel, P. Baseline studies of the clay minerals society source clays: Infrared methods. Clays Clay Miner. 2001, 49, 410-432. [CrossRef]

116. Boudriche, L.; Calvet, R.; Hamdi, B.; Balard, H. Effect of acid treatment on surface properties evolution of attapulgite clay: An application of inverse gas chromatography. Colloids Surf. A Physicochem. Eng. Asp. 2011, 392, 45-54. [CrossRef]

117. Suarez, M.; Garcia-Romero, E. FTIR spectroscopic study of palygorskite: Influence of the composition of the octahedral sheet. Appl. Clay Sci. 2006, 31, 154-163. [CrossRef]

118. Tian, G.; Wang, W.; Kang, Y.; Wang, A. Palygorskite in sodium sulphide solution via hydrothermal process for enhanced methylene blue adsorption. J. Taiwan Inst. Chem. Eng. 2016, 58, 417-423. [CrossRef]

119. Frost, R.L.; Locos, O.B.; Ruan, H.; Kloprogge, J.T. Near-infrared and mid-infrared spectroscopic study of sepiolites and palygorskites. Vib. Spectrosc. 2001, 27, 1-13. [CrossRef]

120. Zou, H.; Cao, Q.; Liu, D.; Yu, X.; Lai, H. Surface Features of Fluorapatite and Dolomite in the Reverse Flotation Process Using Sulfuric Acid as a Depressor. Miner 2019, 9, 33. [CrossRef]

121. Davoodi, M.; Taheran, M.; Brar, K.; Galvez-Cloutier, R.; Martel, R. Hydrophobic dolomite sorbent for oil spill clean-ups: Kinetic modeling and isotherm study. Fuel 2019, 251, 57-72. [CrossRef]

122. Tian, G.; Wang, W.; Mu, B.; Kang, Y.; Wang, A. Facile fabrication of carbon/attapulgite composite for bleaching of palm oil. J. Taiwan Inst. Chem. Eng. 2015, 50, 252-258. [CrossRef]

123. Rhouta, B.; Zatile, E.; Bouna, L.; Lakbita, O.; Maury, F.; Daoudi, L.; Lafont, M.C.; Amjoud, M.; Senocq, F.; Jada, A. Comprehensive physicochemical study of dioctahedral palygorskite-rich clay from Marrakech High Atlas (Morocco). Phys. Chem. Miner. 2013, 40, 411-424. [CrossRef]

124. Zhang, Y.; Wang, W.; Zhang, J.; Liu, P.; Wang, A. A comparative study about adsorption of natural palygorskite for methylene blue. Chem. Eng. J. 2015, 262, 390-398. [CrossRef]

125. Liu, Q.; Yao, X.; Cheng, H.; Frost, R.L. An infrared spectroscopic comparison of four Chinese palygorskites. Spectrochim. Acta Part A Mol. Biomol. Spectrosc. 2012, 96, 784-789. [CrossRef] [PubMed]

126. Ouyang, J.; Zhao, Z.; Suib, S.L.; Yang, H. Degradation of Congo Red dye by a $\mathrm{Fe}_{2} \mathrm{O}_{3} @ \mathrm{CeO}_{2}-\mathrm{ZrO}_{2} /$ Palygorskite composite catalyst: Synergetic effects of $\mathrm{Fe}_{2} \mathrm{O}_{3}$. J. Colloid Interface Sci. 2019, 539, 135-145. [CrossRef] 
127. Cheriaa, J.; Khaireddine, M.; Rouabhia, M.; Bakhrouf, A. Removal of triphenylmethane dyes by bacterial consortium. Sci. World J. 2012, 2012, 512454. [CrossRef]

128. Abdi, M.; Balagabri, M.; Karimi, H.; Hossini, H.; Rastegar, S.O. Degradation of crystal violet (CV) from aqueous solutions using ozone, peroxone, electroperoxone, and electrolysis processes: A comparison study. Appl. Water Sci. 2020, 10, 168. [CrossRef]

129. Jabar, J.M.; Odusote, Y.A.; Alabi, K.A.; Ahmed, I.B. Kinetics and mechanisms of congo-red dye removal from aqueous solution using activated Moringa oleifera seed coat as adsorbent. Appl. Water Sci. 2020, 10, 136. [CrossRef] 